\title{
UNA VIDA DE RESISTENCIA PASIVA DESDE LA INGENIERÍA
}

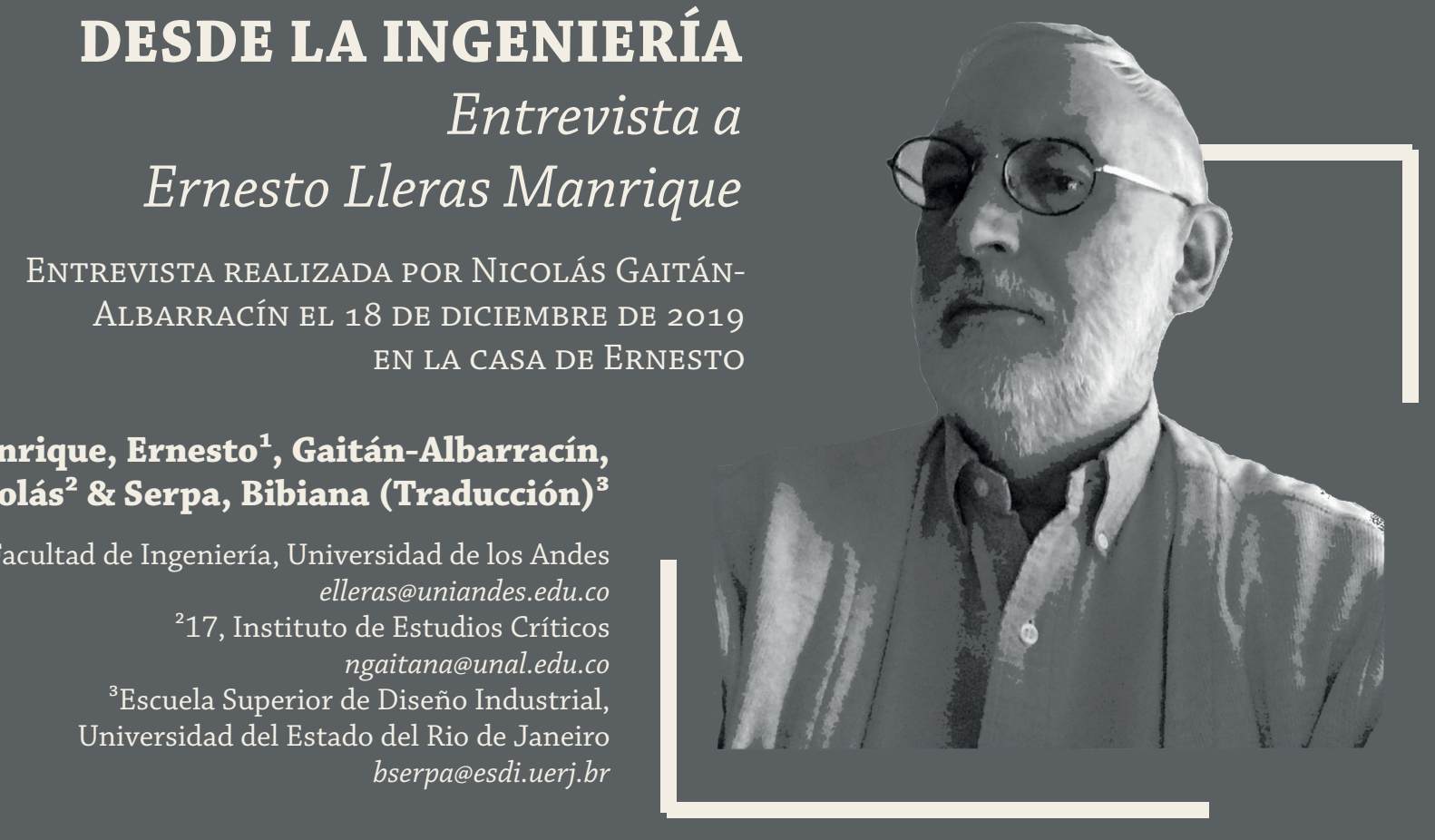

LLeras Manrique, Ernesto ${ }^{1}$, Gaitán-Albarracín, Nicolás $^{2}$ \& Serpa, Bibiana (Traducción) ${ }^{3}$

\footnotetext{
${ }^{1}$ Facultad de Ingeniería, Universidad de los Andes elleras@uniandes.edu.co ngaitana@unal.edu.co ${ }^{3}$ Escuela Superior de Diseño Industrial, bserpa@esdi.uerj.br
}

UMA VIDA DE RESISTENCIA PASSIVA A PARTIR DA ENGENHARIA Entrevista com Ernesto Lleras Manrique

ENTREVISTA REALIZADA POR NICOLÁS GAITÁNALBARRACÍN EM 18 DE DEZEMBRO DE 2019 NA CASA DE ERNESTO

LLeras Manrique, Ernesto ${ }^{1}$, Gaitán-Albarracín, Nicolás ${ }^{2}$ \& Serpa, Bibiana (Tradução) ${ }^{3}$

${ }^{1}$ Faculdade de Engenharia, Universidade dos Andes elleras@uniandes.edu.co

${ }^{2} 17$, Instituto de Estudos Críticos ngaitana@unal.edu.co

${ }^{3}$ Escola Superior de Desenho Industrial, Universidade do Estado do Rio de Janeiro bserpa@esdi.uerj.br 
Ernesto LLerena-Manrique es Ingeniero Eléctrico de la Universidad de los Andes, con estudios de doctorado en Sistemas Complejos del Instituto de Tecnología de Massachusetts (MIT) y magíster en Estrategias de comunicación y estructura organizacional de la Universidad de Pennsylvania, Estados Unidos. Además, es un pionero de la Ingeniería de Sistemas en Colombia, experto en sistemas organizacionales, aprendizaje organizacional e intervención con tecnología en organizaciones. Dentro de su apuestas intelectuales se destaca el enfoque Teoría de Sistema en las Organizaciones-TESO y Comunidades de Aprendizaje. Su trabajo se ha caracterizado por pensar la tecnología con la gente y la búsqueda del sentido en cada una de nuestras prácticas.
Ernesto LLerena-Manrique é formado em Engenharia Elétrica pela Universidad de los Andes, possui doutorado em Sistemas Complexos pelo Massachusetts Institute of Technology (MIT) e mestrado em Estratégias de Comunicação e Estrutura Organizacional pela University of Pennsylvania, EUA. É também pioneiro da Engenharia de Sistemas na Colômbia, especialista em sistemas organizacionais, aprendizagem organizacional e intervenção com tecnologia nas organizações. Dentro do seu compromisso intelectual, destaca-se a abordagem da Teoria do Sistema nas Organizações-TESO e das Comunidades de Aprendizagem. Seu trabalho tem se caracterizado por pensar em tecnologia com as pessoas e a busca de sentido em cada uma de nossas práticas. 
Nos encontramos con Ernesto en un soleado día decembrino, rodeado por su inmensa colección de libros y los árboles que protegen su casa. Después de divagar un poco sobre nuestra cotidianidad nos dispusimos a empezar la entrevista. Él recién llegaba a la ciudad y aún venía con la tranquilidad del campo pegada a su ser. Le pregunté si había podido revisar las preguntas, pero él no sabía de qué le estaba hablando. Entonces, sin más que decir le pedí que nos contará un poco de su vida para dejar fluir la conversación.

Nicolás Gaitán-Albarracín: Cuéntanos un poco sobre quién eres tú y qué has hecho en tu vida profesional en resonancia con estas prácticas de una ingeniería un "poco diferente".

Ernesto LLeras Manrique: Estudié Ingeniería Eléctrica, pero nunca la ejercí y antes de graduarme empecé a ejercer la Ingeniería de Sistemas porque entré a trabajar con IBM. En mi trabajo me encontré con que me tocaba diseñar sistemas de información en el sector financiero y a la gente no le gustaba que le impusieran metodologías que les cambiaran su manera de hacer las cosas. Y que, como tu sabes, los enfoques de computación son como el Tractatus ${ }^{1}$ de Wittgenstein, un ladrillo y además se les imponen a la gente, son muy rígidas y la gente, sobre todo en nuestra cultura, es muy ingeniosa, muy creativa y no se aguanta que le impongan cosas rígidas.

Entonces empecé a pensar que mi trabajo iba a ser un desastre, porque iba a ir en contravía de la gente y era un trabajo que era imponer a la gente unas lógicas contra-natura. Eso me empezó a angustiar mucho porque yo creía que lo que yo hacía era bello y buenísimo y a la gente no le gustaba. Por otra parte, mi experiencia en una organización como esta tampoco me gustó, porque era también, una experiencia de dominación. La misma gente de ahí, decía que era como una especie de gallinero en la que los de arriba se cagan en los de abajo. Aunque yo rápidamente fui escalando por mi preparación y por mi carácter, muy probablemente. Eso me perturbaba muchísimo, yo me sentía en contravía de la vida ahí metido.

Después de durar tres años en IBM, me pasé a la Universidad (de los Andes) y eso si fue realmente la libertad. Me pasé como director del Centro de Cómputo, porque en ese momento no había ingenieros

1 Referencia al Tractatus Logico-Philosophicus de Wittgenstein L., libro del que veníamos conversando antes de la en
Encontramos Ernesto em um dia ensolarado de dezembro, cercado por sua imensa coleção de livros e pelas árvores que protegem sua casa. Depois de um pouco de digressão sobre a nossa vida cotidiana, começamos a entrevista. Ele tinha acabado de chegar à cidade e ainda vinha com a tranquilidade do campo ligada ao seu ser. Perguntei-lhe se ele tinha sido capaz de rever as perguntas, mas ele não sabia do que eu estava falando. Então, sem mais delongas, pedi-lhe para nos contar um pouco sobre a sua vida para deixar a conversa fluir.

\section{Nicolás Gaitán-Albarracín: Conte-nos um pou- co sobre quem é você e o que você fez na sua vida profissional em ressonância com estas práticas de uma engenharia "um pouco diferente".}

Ernesto LLeras Manrique: Eu estudei Engenharia Elétrica, mas nunca a exerci e antes de me formar eu comecei a atuar em Engenharia de Sistemas porque comecei a trabalhar com a IBM. No meu trabalho descobri que tinha de desenhar sistemas de informação no setor financeiro e as pessoas não gostavam quando lhes eram impostas metodologias que mudavam a sua maneira de fazer as coisas. E que, como sabem, as abordagens computacionais são como o Tractatus ${ }^{1}$ de Wittgenstein, um tijolo e são impostas às pessoas, são muito rígidas e as pessoas, especialmente na nossa cultura, são muito engenhosas, muito criativas e não suportam ser impostas a elas.

Então comecei a pensar que o meu trabalho seria um desastre, porque se daria contra o povo e era um trabalho que imporia às pessoas uma lógica contranatural. Isso começou a me angustiar muito porque eu acreditava que o que eu estava fazendo era bonito e muito bom mas as pessoas não gostavam. Por outro lado, também não gostei da minha experiência numa organização como esta, porque foi também uma experiência de dominação. As pessoas ali disseram que era como uma espécie de galinheiro onde os de cima cagam na parte de baixo. Embora eu tenha escalado rapidamente devido à minha preparação e ao meu carácter, provavelmente. Isso me perturbou muito, me senti contra a vida lá.

Depois de três anos na IBM, fui para a Universidade (dos Andes) e isso foi realmente libertador. Eu me tornei diretor do Centro de Informática porque naquela época não havia engenheiros de sistemas e a carreira de sistemas estava apenas começando

1 Referência ao Tractatus Logico-philosophicus de Wittgenstein, L., um livro sobre o qual tínhamos falado antes da entrevista. 
de sistemas y la carrera de sistemas estaba empezando (1969). Entonces no había mucha gente preparada formalmente en ese tema, por eso pude ser muy joven el director del centro de computo. Yo tenía ese gusanillo dentro, pero yo sabía que como era ingeniero eléctrico, tenía que hacer una Maestría en computadores para poder ejercer porque no tenía, digamos, un estudio formal. Como ya estaba en la Universidad me dieron una beca de la Fundación Ford para ir a estudiar en la Universidad de Pennsylvania "Computer Science". Cuando estaba allá, yo me preguntaba: "¿yo qué voy a hacer con esto en Colombia, con esto qué es tan rígido, tan anglosajón?"; "creo que en Colombia hay que empezar a buscar caminos propios" pensaba yo; lo pensé siempre, desde niño. Así, terminé mi maestría, ya al final un poco harto y me metí en otra maestría que no me querían dejar entrar, porque no tenía antecedentes en ciencias sociales, que era de "Comunicación Organizacional". Allí había un departamento muy famoso que es el "Annenberg School for Communication" y entonces me metí ahí, y me pusieron como requisito que hiciera un curso y si me iba bien me admitían y si no, nada. Me fue muy bien, pero claro el curso era muy afín a lo mío, porque era un curso de modelos cibernéticos. Entonces hice la maestría en "Comunicación Organizacional" y con este par de maestrías me vine, porque yo tenía un compromiso moral con la universidad, no me presté para firmar nada, nunca me he dejado que me matoneen, entonces yo no firmé un papel para obligarme a venir, pero vine.

"Y la otra tesis si fue sobre el ejercicio del poder en las organizaciones, como vez, yo estaba obsesionado con eso, y lo sigo, eso ha sido una de mis obsesiones en la vida iporque a mi el poder me cae en las pelotas!
(1969). Naquela época não havia muitas pessoas capacitadas formalmente nesse assunto, então eu pude ser diretor do centro de informática muito jovem. Eu tinha aquele pequeno verme dentro de mim, mas eu sabia que como eu era um engenheiro elétrico, eu teria que fazer um mestrado em computadores para poder atuar porque eu não tinha, digamos, uma educação formal. Como já estava na universidade, recebi uma bolsa da Fundação Ford para ir para a Universidade da Pensilvânia estudar Ciência da Computação. Quando estava lá me perguntei: "O que vou fazer com isso na Colômbia, com isso, que é tão rígido, tão anglo-saxão?; acho que a Colômbia tem que começar a procurar "seus próprios caminhos", eu pensei; sempre pensei isso, desde criança. Então, terminei meu mestrado, e no final me fartei e entrei em outro mestrado que eles não queriam me deixar entrar, porque eu não tinha formação em ciências sociais, que era "Comunicação Organizacional". Havia lá um departamento muito famoso, a "Annenberg School for Communication" e por isso me interessei, e eles exigiram como requisito que eu fizesse um curso e se eu me saísse bem eles me admitiriam e se não, nada. Eu me saí muito bem, mas é claro que o curso era muito parecido com o meu, porque era um curso de modelagem cibernética. Então fiz o mestrado em "Comunicação Organizacional" e com estes dois mestrados voltei, porque tinha um compromisso moral com a universidade, não assinei nada, nunca me deixei intimidar, por isso não assinei um papel para me forçar a voltar, mas voltei.
\E a outra tese era sobre o exercício do poder nas organizações, como você pode ver, eu estava obcecado com isso, e eu ainda estou, isso tem sido uma das minhas obsessões na vida, porque o poder é como um chute no saco! 


\section{NGA: En ese momento ustedes tenían que desarro- llar trabajos de grado en esas maestrías, ¿sobre qué trabajaste?}

ELM: Si, claro. En la maestría en "Computer Science" empecé a hacer una tesis de un modelo de comunicación binaria desde la perspectiva de la inteligencia artificial, usando teorías de Piaget, entre otras cosas. Pero, después cuando resolví hacer la otra maestría y estaba harto, deje eso y me fui por un caminito que le ofrecían a uno de tomar un curso extra y le daban la maestría sin necesidad de tesis. Entonces no terminé esa tesis, aunque fue muy interesante la experiencia. Y la otra tesis si fue sobre el ejercicio del poder en las organizaciones, como ves, yo estaba obsesionado con eso, y lo sigo estando, eso ha sido una de mis obsesiones en la vida iporque a mi el poder me cae en las pelotas! En el 72- 73, no me acuerdo bien, volví como profesor de "Computer Science", porque no había otra opción. Sin embargo, el jefe de Departamento me dijo: "Usted debería inventarse un curso con todo lo que ha hecho", y yo pensando lo que podría hacer para Colombia me inventé un curso que fue supremamente exitoso, Modelaje Cibernético.

Cuando volví, me encontré con que habían puesto maestrías en ingeniería, y yo estaba completamente en desacuerdo en poner maestrías cuando no hay madurez investigativa. Aunque la maestría no necesariamente es investigativa, es fundamental que los profesores tengan experiencia en investigación para poder hacer una maestría, según yo, en ese momento. Ahora creo que la cosa es más complicada. Yo me opuse fieramente a las maestrías y me nombraron, porque me opuse, como director en la Maestría en Computación y como director de la maestría en computación pertenecía a un comité de maestrías en ingeniería. Ahí, no solo hice la crítica, sino que me puse a investigar los problemas financieros, académicos, como era el asunto de las maestrías, investigué en todas partes y escribí un montón de documentos y demostré que era necesario tener un ente que apoyara a los profesores en el desarrollo de la investigación para que ellos aprendieran a investigar investigando, que fue lo que se llamó el CIFI, el Centro de Investigación de la Facultad de Ingeniería.

Ahí yo empecé a trabajar también en proyectos de sistemas grandotes que contrataban con la Universidad. Porque yo también tenía el argumento de que la universidad podía apoyar la investigación en

\section{NGA: Naquela época você tinha que desenvolver trabalhos de pós-graduação nesses mestrados, em que trabalhava?}

ELM: Sim, certo. No meu mestrado em Ciência da Computação, comecei a escrever uma tese sobre um modelo de comunicação binária a partir da perspectiva da inteligência artificial, usando as teorias de Piaget, entre outras coisas. Mas, mais tarde, quando decidi fazer o outro mestrado e fiquei farto, deixei isso de lado e fui por um caminho que eles ofereciam de fazer um curso extra e obter o grau de mestre sem a necessidade de uma tese. Por isso não terminei essa tese, embora tenha sido uma experiência muito interessante. $\mathrm{E}$ a outra tese era sobre o exercício do poder nas organizações, como você pode ver, eu estava obcecado com isso, e eu ainda estou, isso tem sido uma das minhas obsessões na vida, porque o poder é como um chute no saco. Em 72-73, não me lembro bem, voltei como professor de Ciências da Computação, porque não havia outra opção. Entretanto, o chefe do Departamento me disse: "Você deveria inventar um curso com tudo o que você fez", e eu pensei no que eu poderia fazer pela Colômbia e inventei um curso que foi extremamente bem sucedido, "Modelagem Cibernética".

Quando voltei, descobri que eles tinham aberto cursos de mestrado em engenharia, e eu estava completamente em desacordo com abertura de mestrado quando não há maturidade na pesquisa. Embora um mestrado não seja necessariamente baseado em pesquisa, é essencial que os professores tenham experiência de pesquisa para fazer um mestrado, na minha opinião, naquele momento. Agora acho que é mais complicado do que isso. Eu era ferozmente contra os mestrados e fui nomeado, porque me opus, como diretor do mestrado em ciência da computação e como diretor do mestrado em ciência da computação eu pertencia a uma comissão de mestrado em engenharia. Lá, não só fiz as críticas, mas comecei a investigar os problemas financeiros e acadêmicos, como era a questão dos mestrados, pesquisei por toda parte e escrevi muitos documentos e demonstrei que era necessário ter uma entidade que apoiasse os professores no desenvolvimento da pesquisa para que eles aprendessem a fazer pesquisa, que era o que depois se chamou CIFI, o Centro de Pesquisa da Escola de Engenharia.

Lá também comecei a trabalhar em projetos de grandes sistemas contratados com a Universidade. 
ingeniería, si apoyaba proyectos que permitían que los profesores salieran al mundo y aprendieran haciendo. Además, me inventé toda una teoría de lo que es investigación en ingeniería, porque es diferente a la investigación científica, es prueba y error; es en la práctica, no es basado en teoría que uno refuta, a la Popper, uno trata de refutar las hipótesis, que son construidas con base en teoría. Aquí, lo que podríamos decir equivalente a la teoría es el recuento de las prácticas y es muy interesante porque cuando estaba más grande hice una historia de la ingeniería, y ahi vi que así era como se había formado la ingeniería con prueba-error y ensayos en vivo. Bueno, en ese momento era pura intuición, y se formó el CIFI y la Universidad lo apoyó y yo me fui otra vez a hacer el doctorado.

"Porque como tu sabes, ese es otro problema de la educación en Colombia. Aquí, uno estudia lo que toca y no lo que le gusta. "Y yo trataba de que la gente hiciera lo que les gusta, $y$ eso no es fácil, para nada.

NGA: Tu abriste ahí una puerta que fue interesante, pero no contaste más, creaste un curso de Modelaje Cibernético, ¿nos puedes contar un poco de cómo era ese curso?

ELM: El curso fue muy clave para la gente que paso pora ahi, y me lo han dicho, algunos. En ese curso yo buscaba que la gente desarrollará sus pasiones intelectuales. Fue crucial para sus vidas, porque les determinó para hacer lo que verdaderamente ellos estaban capacitados para hacer. Porque como tu sabes, ese es otro problema de la educación en $\mathrm{Co}^{-}$ lombia. Aquí, uno estudia lo que toca y no lo que le gusta. Y yo trataba de que la gente hiciera lo que les gusta, y eso no es fácil, para nada. Sus "Vocaciones Vitales", pues en ese momento yo no la llamaba así. Varios de mis alumnos que pasaron por ahí, se volvieron estrellas, porque a mí me criticaban "porque usted no hacía ingeniera, usted es un loco que hace unas cosas rarísimas".

Resulta que los estudiantes que pasaron por ahí fueron los más exitosos, porque hacían lo que les
Porque eu também tinha o argumento de que a universidade poderia apoiar a pesquisa em engenharia, se ela apoiasse projetos que permitissem aos professores sair para o mundo e aprender fazendo. Além disso, eu inventei toda uma teoria do que é pesquisa de engenharia, porque é diferente da pesquisa científica, é tentativa e erro; não é baseado em teoria que você a refuta, a la Popper, você tenta refutar hipóteses, que são construídas sobre teoria. Aqui, o que poderíamos dizer equivalente à teoria é a contagem das práticas e é muito interessante porque quando eu estava mais velho eu fiz uma história da engenharia, e eu vi que era assim que a engenharia era formada com tentativas e erros e testes ao vivo. Bem, naquela época era pura intuição, e o CIFI foi formado e a Universidade o apoiou e eu fui novamente fazer o doutorado.

\section{„Porque, como sabes, esse é outro problema de educação na Colômbia. Aqui você estuda o que deve e não o que você gosta. E eu tentei algo para que as pessoas fizessem o que gostavam, $e$ isso não é fácil.}

\begin{abstract}
NGA: Você abriu uma porta que foi interessante, mas não contou muito. Você criou um curso de Modelagem Cibernética, pode nos dizer um pouco mais sobre como era esse curso?
\end{abstract}

ELM: Esse curso foi muito importante para as pessoas que passaram por lá, e me disseram isso, algumas delas. Nesse curso eu estava procurando por pessoas para desenvolver suas paixões intelectuais. Foi crucial para as suas vidas, porque os ajudou a fazer o que eram verdadeiramente capazes de fazer. Porque, como sabes, esse é outro problema de educação na Colômbia. Aqui você estuda o que deve e não o que você gosta. E eu tentei algo para que as pessoas fizessem o que gostavam, e isso não é fácil. As suas "Vocaciones Vitales", porque nessa altura não lhe chamava isso. Vários dos alunos que passaram por ali tornaram-se estrelas. Criticaramme "você não fez engenharia, você é um louco que faz algumas coisas muito estranhas". Acontece que os alunos que passaram por ali foram os mais bem 
gustaba. Pero además ¡comprendieron!, este curso tiene una dimensión filosófica que lo inserta a uno dentro del mundo de la realidad. El curso como yo lo hice era modelar la realidad, de un manera que hoy veo como de un primitivo, además muy ingenua, porque era muy dominadora, pero eso era el modelo colonialista, que hasta ahora empiezo a criticar. En eso he sido muy, podría decirse, irresponsable, pero por el otro lado muy responsable. Yo me daba cuenta de lo complicado que era el enfoque colonialista, pero digamos el cambio que yo empecé a hacer duró mucho tiempo.

\section{NGA: ¿Cómo eran aquellos cursos?, ¿Cómo las per- sonas aprendian?}

ELM: Digamos que yo hacía esos talleres de "Vocaciones Vitales", que todavía hago. Y los estudiantes descubrían lo que les gustaba, y cuando lo descubrían yo les proponía que diseñarán un proyecto de investigación sobre eso y que usaran la metodología cibernética, que era lo que tenían a mano. Junto a ese curso, me inventé un curso de trabajo de campo, que era salir a la ciudad a hacer proyectos. $Y$ en eso tuvo un impacto en la ciudad impresionante; diseñamos, por ejemplo, un sistema de puntos de atención ciudadana con computación, en la que la gente podía ir a tramitar todas sus cosas con el Distrito, y si les daba un yeyo, allí le decían a donde ir y todo eso. Eso se volvió en los $\mathrm{CADE}^{2}$. Otra cosa interesante fue que hicimos un mapa digital de Bogotá para catastro y eso se convirtió en el $\mathrm{SISE}^{3}$, que es el centro de computación de la ciudad y de catastro, donde está toda la ciudad en sistema de información georeferenciada, catastro y todo eso. $Y$ eso lo hicieron mis estudiantes. Lo fascinante era que esos estudiantes desde el principio ya estaban haciendo cosas, no era pura teoría o pura cosa abstracta, sino con las manos en la masa.

Además, dí varios cursos en esa época desde Ingeniería de Sistemas, de programación, de modelos de información lógicos para computadores, estructuras de datos y de ese estilo. Pero un dia yo dije, en uno de estos cursos: "yo no sé y no voy a seguir

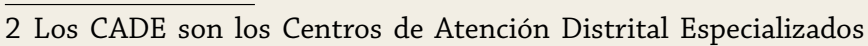
donde las entidades públicas del orden distrital y nacional, las empresas de servicios públicos domiciliarios y algunas entidades privadas se articulan para prestar un servicio integral a la ciudadanía, en información, asesoría y trámites. Recuperado el 6 de enero de 2020 en: https://secretariageneral.gov.co/servicio-ciudadania/presencial/cade

3 Los SISE son los Centro Distrital de Sistematización y Servicios Técnicos, funcionaron en Bogotá hasta el año 2002. sucedidos, porque fizeram o que gostavam. Mas eles também entenderam que este curso tem uma dimensão filosófica que os insere no mundo da realidade. O curso como eu o fiz foi para modelar a realidade de uma forma que hoje vejo como primitiva, também muito ingênua, porque era muito dominante, mas esse era o modelo colonialista, que começo a criticar. Nisso tenho sido muito, pode-se dizer, irresponsável, mas, por outro lado, muito responsável. Percebi como a abordagem colonialista era complicada, mas digamos que a mudança que comecei a fazer durou muito tempo.

\section{NGA: Como foram essas aulas? Como as pessoas aprendiam?}

ELM: Digamos que eu fiz oficinas de "Vocaciones Vitales", o que ainda faço. E os alunos entendiam do que gostavam e, quando descobriam, eu propunha que desenhassem um projeto de pesquisa e usassem a metodologia cibernética, que era o que tinham em mãos. Junto com esse curso, inventei um curso de pesquisa de campo, saímos para a cidade para fazer projetos. E isso teve um impacto impressionante na cidade. Projetamos, por exemplo, um sistema de pontos de atenção do cidadão com sistema de computação, no qual as pessoas poderiam processar todas as suas coisas com o Distrito e, se lhes resultasse em um erro, o sistema diria a eles para onde ir e tudo mais. Isso se tornou o $\mathrm{CADE}^{2}$. Outra coisa interessante foi que fizemos um mapa digital de Bogotá para cadastro e que se tornou o $\mathrm{SISE}^{3}$, que é o centro de informática da cidade e cadastro, onde toda a cidade está em sistema de informação georreferenciada, cadastro e tudo isso. $\mathrm{E}$ isso foi feito pelos meus alunos. O fascinante era que aqueles alunos do começo já estavam fazendo coisas, não era pura teoria ou pura coisa abstrata, mas com as mãos na massa.

Além disso, eu dei vários cursos de Engenharia de Sistemas, programação, modelos lógicos de informação para computadores, estruturas de dados e assim por diante. Mas um dia eu disse, em um desses cursos: "Eu não sei e não vou continuar dando

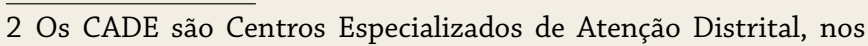
quais entidades públicas do distrito e ordem nacional, empresas domiciliares de serviços públicos e algumas entidades privadas são articuladas para prestar um serviço abrangente aos cidadãos, em informações, conselhos e procedimentos. Acessado em 6 de janeiro de 2020 em: https://secretariageneral.gov.co/servicio-ciudadania/ presencial/cade

3 O SISE é o Centro Distrital de Sistematização e Serviços Técnicos, operado em Bogotá até 2002. 
dando estos cursos". Yo sí sabía, claro, pero consideraba que no sabía lo suficiente, consideraba que uno debería ser un genio para poder enseñar y los que tomaron el curso me dicen siempre: "usted es un referente para mí porque ese curso fue muy importante para mí... usted fue crucial ahí porque me hizo entender la base filosófica", y ahi te muestra otra cosa mía, que es esa pasión por la filosofía. Es decir por reflexionar sobre el sentido de lo que hago y el sentido de lo que uno hace y eso en mis cursos y tú lo has visto en las "Comunidades de Aprendizaje” y es la obsesión por el sentido.

\section{NGA: Entonces para tí, ¿la filosofía es eso, es re- flexionar sobre el sentido de lo que uno hace?}

ELM: Pues sí, no es la filosofía, es la filosofía en eso, la filosofía yo no sé qué será. En la práctica se refleja en que, lo que yo hago tiene sentido y para poder tener sentido, tengo que reflexionar y por ejemplo, darme cuenta cómo está inserto en un contexto. ¿Qué es la esencia del sentido?, es ser capaz uno de darse cuenta del contexto donde uno está haciendo lo que está haciendo, o sea, si yo hago por ejemplo manifestaciones, como ahora están haciendo. Lo que hay es aparentemente una inconformidad sobre un montón de cosas, pero no hay algo coherente. En el fondo hay una profunda insatisfacción con el sistema, uno entiende eso. Pero claro, yo tengo que manifestar porque estoy profundamente descontento con el sistema, yo aún no sé qué solución dar, pero tengo que manifestarme.

Eso es interesantísimo porque yo desde chiquito tengo eso, y una vez me dijo mi mama: "mijo todos teníamos tantas esperanzas en ti y no saliste con nada" y respondí: "y es verdad, no sali con nada y por una razón muy sencilla, porque ustedes han hecho un país desastroso, yo considero que es desastroso, no me gusta. Pero no tengo alternativa, no sé que proponer alternativamente, por eso no he hecho nada, no puedo meterme dentro del sistema porque lo detesto". Y si me hubiera metido probablemente hubiera llegado lejos, pero hubiera llegado lejos como una puta (es un decir, porque respeto mucho todas las opciones de vida).

Digamos que hice lo que he hecho, que es una forma, digámoslo de "resistencia pasiva", como Gandhi. Que es ir viendo por qué camino coger, y creo precisamente que "Comunidades de Aprendizaje"

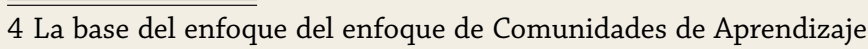

esses cursos”. Eu sabia, claro, mas considerava que não sabia o suficiente, considerava que precisaria ser um gênio para poder ensinar e aqueles que fizeram o curso sempre me dizem: "você é uma referência para mim porque esse curso era muito importante para mim... você foi crucial lá porque me fez entender as bases filosóficas", e isso mostra outra coisa minha, que é essa paixão pela filosofia. Isto é, refletir sobre o significado do que eu faço e o significado do que se faz e que nos meus cursos e vocês viram nas "Comunidades de Aprendizagem" e é a obsessão pelo significado.

\section{NGA: Então para você, é isso que é filosofia? É re- fletir sobre o significado do que se faz?}

ELM: Bem, sim, não é filosofia, é a filosofia nisso, a filosofia eu não sei o que é. Na prática, isso se reflete em: o que eu faço tem sentido, e para ter sentido, tenho que refletir e, por exemplo, perceber como estar inserido em um contexto. O que é a essência do sentido? É poder perceber o contexto onde se está fazendo o que se está fazendo, ou seja, se eu faço, por exemplo, manifestações, como estão fazendo agora. O que aparentemente existe é uma não-conformidade com muitas coisas, mas não há algo coerente. No fundo, há uma profunda insatisfação com o sistema, não se compreende isso. Mas, claro, tenho que demonstrar porque estou profundamente insatisfeito com o sistema, ainda não sei que solução dar, mas tenho que me manifestar.

Isso é muito interessante porque desde pequeno tive isso, e uma vez minha mãe me disse: "meu filho, todos nós tínhamos tanta esperança em você e você não está com nada". E eu respondi: "e é verdade, eu não estou com nada e por uma razão muito simples, porque vocês fizeram um país desastroso, eu o considero desastroso, eu não gosto. Mas eu não tenho escolha, não sei o que propor como alternativa, por isso não fiz nada, não posso entrar no sistema porque o odeio". E se eu tivesse me metido nisso, provavelmente teria ido longe, mas teria ido longe como uma puta (isso é uma expressão, porque respeito muito todas as escolhas de vida)..

Digamos que eu fiz o que fiz, que é uma forma de, digamos, "resistência passiva", como Gandhi. Que é ver que caminho seguir, e penso que precisamente "Comunidades de Aprendizagem"4 é uma proposta

4A abordagem das comunidades de aprendizagem baseia-se na premissa de que aprendemos em uma interação permanente de reflexão corporal, baseada na prática consciente. Daí deriva o recon- 
es una propuesta revolucionaria, pero para que la gente haga la revolución, no para que yo les diga que es lo que hay que hacer, como los marxistas o los mamertos ${ }^{5}$, según una teoría chimba de Marx, que no es chimba, es una teoría bonita, pero es chimba en el contexto de la realidad, que es mucho más rica que cualquier teoría. ¡Aquí para que los mamertos de tu universidad me echen pelotas de barro o papas bomba! (risas)

\section{NGA: ...o bombas de semillas, pero volviendo al doctorado ¿En qué era?}

ELM: Me fui a hacer el doctorado en el 79, y ya tenía como treinta y pico de años, eso fue un doctorado medio-chiflis que yo me inventé, pero era para irme, no era que yo tuviera interés en el doctorado, era para irme, porque estaba mamado en los Andes, y yo cada vez que estoy mamado me invento un sabático. Entonces, he tenido varios sabáticos. Como yo había hecho esa tesis de estructuras de poder en organizaciones, a mí me interesaba mucho el problema del poder, entonces me metí en una cosa que era como ciencia política y modelos matemáticos,

consiste en partir del postulado de que aprendemos en una interacción permanente cuerpo-reflexión a partir de la práctica consciente. De allí se deriva el reconocimiento del propio quehacer y su articulación dialógica con los quehaceres de otros dentro de estructuras diversas que emergen de relaciones de poder, comunicación y producción. En estos procesos se va construyendo una comunidad significativa para los participantes, y también de los aprendizajes mismos van emergiendo diversos sentidos que motivan la acción.

Para mirar más a detalle el enfoque de "Comunidades de Aprendizaje" revisar:

- Lleras Manrique, E. Las comunidades de aprendizaje como ámbitos de construcción de mundo. In: M. A. Velilla (Org.); Manual de iniciación pedagógica al Pensamiento Complejo. p.165182, 2002. Quito: UNESCO.

- Lleras Manrique, E. (2010). Del educar al pedagogiar. Polis (Santiago), v. 9, n. 25, p. 235-242.

Lleras, E. (2003). Communities of learning: a case in local development. Kybernetes, 32(5/6), 644-652.

- Gutiérrez, A. y Lleras, E. (2017). Comunidades de aprendizaje: opción frente a la pobreza. En Ingeniería, innovación y tecnología social. Ed. María Belén Albornoz Javier Jiménez Becerra Jorge Rojas Álvarez . Bogotá, Colombia.

- Gutiérrez Pérez, Ángel A., Lleras, E., \& Díaz, J. (2019). Comunidades de Aprendizaje como apoyo a un Sistema de Gestión del Conocimiento y la Innovación. Un estudio de Caso. International Journal of Engineering, Social Justice, and Peace, 6(1), 7-25.

- Communities of Learning as Support for one Knowledge and Innovation Management System: A case study, con A. Gutiérrez y J. Díaz, enviado a Systems Research and Social Practice, 2019.

5 "Mamerto" en Colombia es una persona de izquierda. Es un término despectivo que se asocia a un estereotipo como llevar mochila y poco esmero en el arreglo personal, además de una tendencia discursiva a emplear frases y palabras cliché como "el pueblo", "neoliberalismo", "lucha de clases", entre otros. Es producto de la fuerte estigmatización que sufre la ideología de izquierda en Colombia. Recuperado el 7 de enero en: https://www.las2orillas.co/el-verdaderoorigen-de-mamerto/ revolucionária, mas para que as pessoas façam revolução, não para que eu lhes diga o que fazer, como os marxistas ou os mamertos ${ }^{5}$, segundo uma teoria ridícula de Marx, que não é ridícula, é uma bela teoria, mas é ridícula no contexto da realidade, que é muito mais rica do que qualquer teoria. (risos)

\section{NGA: ... ou bombas de sementes, mas voltando ao doutorado.. O que você fez?}

ELM: Eu fui fazer meu doutorado em 1979, e eu já estava na casa dos trinta anos, isso foi um doutorado meio maluco que eu inventei, mas era para ir embora, não era como se eu tivesse qualquer interesse no doutorado, era para ir embora, porque eu estava me sentindo sugado nos Andes, e toda vez que eu me sinto assim, eu invento um sabático. Então, já tive vários sabáticos. Como eu tinha feito essa tese sobre estruturas de poder nas organizações, eu estava muito interessado no problema do poder, então entrei em algo entre ciência política e modelos matemáticos, para olhar para modelos de poder que eram chamados de "Complexos Sistemas

hecimento do próprio trabalho e sua articulação dialógica com as tarefas de outros dentro de diversas estruturas que emergem das relações de poder, comunicação e produção. Nesses processos, uma comunidade significativa está sendo construída para os participantes e diferentes sentidos que motivam a ação estão emergindo do próprio aprendizado. Acesso em 7 de janeiro de 2020: em:https:// congresoeducacionsistemica.com/schedule/ernesto-lleras-el-enfoque-de-comunidades-de-aprendizaje-como-un-experimento-pedagogico-dos-ejemplos/

Para mirar más a detalle el enfoque de "Comunidades de Aprendizaje", revisar:

- Lleras Manrique, E. Las comunidades de aprendizaje como ámbitos de construcción de mundo. In: M. A. Velilla (Org.); Manual de iniciación pedagógica al Pensamiento Complejo. p.165182, 2002. Quito: UNESCO. L

- Lleras Manrique, E. (2010). Del educar al pedagogiar. Polis (Santiago), v. 9, n. 25, p. 235-242. Lleras, E. (2003). Communities of learning: a case in local development. Kybernetes, 32(5/6), 644-652.

- Gutiérrez, A. y Lleras, E. (2017). Comunidades de aprendizaje: opción frente a la pobreza. En Ingeniería, innovación y tecnología social. Ed. María Belén Albornoz Javier Jiménez Becerra Jorge Rojas Álvarez . Bogotá, Colombia.

- Gutiérrez Pérez, Ángel A., Lleras, E., \& Díaz, J. (2019). Comunidades de Aprendizaje como apoyo a un Sistema de Gestión del Conocimiento y la Innovación. Un estudio de Caso. International Journal of Engineering, Social Justice, and Peace, 6(1), 7-25.

- Communities of Learning as Support for one Knowledge and Innovation Management System: A case study, con A. Gutiérrez y J. Díaz, enviado a Systems Research and Social Practice, 2019

5 "Mamerto" na Colômbia é uma pessoa de esquerda. É um termo depreciativo associado a um estereótipo, como carregar mochila e demonstrar pouco cuidado pessoal, bem como uma tendência discursiva de usar frases e palavras clichê como "o povo", "neoliberalismo", "luta de classes", entre outros . É o produto da forte estigmatização sofrida pela ideologia da esquerda na Colômbia. Acesso em 7 de janeiro em: https://www.las2orillas.co/el-verdadero-origen-demamerto/ 
para mirar modelos de poder que se llamaba "Sistemas decisorios complejos", imaginate eso, ique nombre tan absurdo!. Eso por ejemplo fue una experiencia para mi genial, no lo terminé nunca porque cuando estaba haciendo la tesis, me llamaron para ser director del CIFI y yo dije. jesto es mi oportunidad en la vida!, mientras yo aquí haciendo una tesis, ¡que carajo! Aquí voy a hacer algo que va tener un impacto. Fue genial la experiencia, porque tomé muchos cursos con gente muy importante, de esas que todos dicen que son vacas sagradas y todo eso.

\section{NGA: ¿Y vacas sagradas en qué campos?}

ELM: Tomé cursos en sistemas, cibernética, pero también vi clase con John Rawls ${ }^{6}$, porque yo quería aprender Marxismo, jimaginate! Entonces tomé un curso de filosofía política e hice un trabajo en ese curso que a mi me gusta, a Rawls no le gustó porque me dijo que yo era "demasiado osado", porque no sabía nada de filosofía y me metía a trabajar a Marx ique era tan jodido! Pero me puso "A", pero no le gustó. El trabajo que hice fue sobre la "Teoría de la enajenación o la alienación" de Marx ijuediablos!, eso sí que me sacó la leche porque yo quería estar a la altura de Rawls, y él era un tipo descomunal, fue más o menos amigo mío, pero siempre me criticó que yo era demasiado latinoamericano, me lanzaba a hacer cosas, ahí... jmuy poco serio, pues! Cómo puede usted tratar de hacer a Marx, si usted no conoce bien a Hume, cosas de esas, pues claro yo lo conozco, yo si leí a Hume ahí, pero pues claro yo no aprendí, porque ¡eso es jodido!, ¡Eso es una vaina seria! Todo eso, pero ahí por ejemplo yo me volví serio, porque cuando uno es ingeniero no es serio, porque la ingeniería no es seria.

\section{NGA: ¿Por qué piensas que la ingeniería no es seria?}

ELM: Porque la ingeniería le falta sentido, los ingenieros son mecanicistas y van haciendo cosas ahí sin pensar. A mi juicio un ingeniero serio es un tipo científico, o sea un tipo que piensa y que reflexiona sobre lo que hace y que es crítico de la ingeniería, ¡eso no son los ingenieros nunca! O muy rara vez, pues, claro que hay, pero no es mucho. Y yo si creo que por ahí es el camino y es un camino muy largo de recorrer. de Decisão", imagine isso, que nome absurdo! Essa, por exemplo, foi uma experiência genial para mim, nunca a terminei porque quando estava fazendo a tese, chamaram-me para ser o director da CIFI e eu disse: esta é a minha chance na vida, enquanto estou aqui fazendo uma tese, que diabos! Aqui vou fazer algo que vai ter um impacto. Foi uma grande experiência, porque fiz muitos cursos com pessoas muito importantes, aquelas que dizem ser vacas sagradas e tudo isso.

\section{NGA: E as vacas sagradas em que campos?}

ELM: Eu fiz cursos em sistemas, cibernética, mas também assisti aulas com John Rawls ${ }^{6}$, porque eu queria aprender marxismo, imagine isso! Então eu fiz um curso de filosofia política e fiz um trabalho nesse curso que eu gosto, Rawls não gostou porque ele disse que eu era "muito ousado", porque eu não sabia nada sobre filosofia e eu comecei a trabalhar no Marx que era tão fodido! Ele me deu um "A", mas não gostou de mim. O trabalho que eu fiz foi sobre a "Teoria da Alienação" de Marx, e isso realmente me pegou porque eu queria estar à altura do Rawls, e ele era um cara grande, era mais ou menos meu amigo, mas ele sempre me criticou por ser muito latino-americano, por me jogar nas coisas,... muito pouco sério, então! Como você pode tentar fazer coisas a partir de Marx, se você não conhece bem o Hume, coisas assim. Claro que eu o conheço, eu li Hume lá, mas claro que não aprendi, porque isso é fodido! Isso é uma coisa séria. Tudo isso, mas lá, por exemplo, fiquei sério, porque quando se é engenheiro não se é sério, porque a engenharia não é séria.

\section{NGA: Por que você acha que a engenharia não é séria?}

ELM: Porque falta significado à engenharia, os engenheiros são mecânicos e andam por aí fazendo coisas sem pensar. Na minha opinião um engenheiro sério é um cara científico, é um cara que pensa e reflete sobre o que faz e é crítico em relação à engenharia, o que nenhum engenheiro é! Ou muito raramente, bem, é claro que há, mas não são muitos. $\mathrm{E}$ eu acredito que este é o caminho e é um longo caminho a percorrer.

6 John Rawls foi um filósofo estadunidense, professor de filosofia política na Universidade de Harvard se destacou por seu trabalho sobre justiça e democracia.

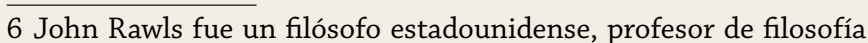
política en la Universidad Harvard se destacó por su trabajo sobre justicia y democracia. 


\section{"Porque la ingeniería le falta sentido, los ingenieros son mecanicistas y van haciendo cosas ahí sin pensar}

NGA: Siempre he sentido esas criticas hacia la ingenieria de tu parte, entonces ¿por qué decidiste quedarte dentro la ingeniería?

ELM: Por esos mismo, porque yo era profesor y pensé que era la única manera, uno no puede estar criticando sin proponer. Yo propongo y hago, todo lo que yo he hecho en mi carrera ha sido una exploración en aprendizaje, liberador, emancipatorio, bla bla, todo eso, que es lo que permitiría hacer una ingenieria seria. Y cuando yo me meti a dirigir el centro de investigación era pensando en eso, yo no me lo sé todo, yo no sé cual es la buena investigación, pero yo sé que la buena investigación es la que nos permite ser serios.

NGA: ¿Entonces volviste a ser Director del Centro de Investigación de la Facultad de Ingeniería?

ELM: Yo me volví a ser director y fui director mucho tiempo, como seis años. Estructuré una vaina que me criticaron mucho. Hice un estructura que permitía que los profesores investigaran, se desarrolló enormemente la investigación en la Facultad, antes me decían "para qué investigar si eso lo hacen en los países desarrollados”, ¡Uy dios, la mentalidad de los Andes ahora que pienso si era verdaderamente horrorosa! Y yo tenía esa idea de que este país tiene que ser autónomo y no se qué, y llegar por su cuenta a ser un país un autónomo. Escribí una cosa que fue muy importante en su momento, que era toda una teoría de cómo se investiga en ingeniería, y como sustentar la investigación en las universidades, porque las universidades no tienen plata para investigar. Entonces, yo me inventé esa cosa de prestación de servicios (que no era nada común en esa época) y se decía que no se podía hacer, porque eso era que la universidad hiciera competencia desleal con sus egresados. Me inventé un artículo que presenté en un seminario latinoamericano y la gente quedó descrestada con eso, porque la gente

\section{»Porque falta significado à engenharia, os engenheiros são mecânicos e andam por aí fazendo coisas sem pensar.}

\section{NGA: Sempre senti essa crítica à engenharia da sua parte, então por que decidiu ficar na engenharia?}

ELM: Por essas mesmas razões, porque eu era professor e achava que era a única maneira, não se pode criticar sem propor. Proponho e faço, tudo o que tenho feito na minha carreira tem sido uma exploração em aprendizagem, libertador, emancipatório, bla bla, tudo isso, o que me permitiria fazer engenharia séria. E quando comecei a dirigir o centro de pesquisa estava pensando nisso, não sei tudo, não sei o que é uma boa pesquisa, mas sei que uma boa pesquisa é o que nos permite ser sérios.

\section{NGA: Então você voltou a ser o Diretor do Centro de Pesquisa da Escola de Engenharia?}

ELM: Voltei a ser director e fui director durante muito tempo, cerca de seis anos. Estruturei uma coisa que foi muito criticada. Fiz uma estrutura que permitiu aos professores fazerem pesquisa, a pesquisa se desenvolveu enormemente na Faculdade, antes disso eles me diziam "por que pesquisar se fazem isso em países desenvolvidos?", meu Deus, a mentalidade dos Andes, agora que penso, era verdadeiramente horrível! E eu tinha esta ideia de que este país tem de ser autônomo e não sei o quê, e tornar-se um país autônomo por si só. Escrevi algo que foi muito importante na época, que era toda uma teoria de como fazer pesquisa em engenharia, e como apoiar a pesquisa nas universidades, porque as universidades não têm dinheiro para pesquisa. Então, eu inventei essa coisa de prestação de serviços (que não era comum naquela época) e foi dito que não podia ser feito, porque isso seria a universidade competindo injustamente com seus egressos. Inventei um artigo que apresentei num seminário latino-americano e as pessoas ficaram chocadas com ele, porque elas não tinham pensado no assunto. Como apoiar a pesquisa da universidade num sistema capitalista que não está interessado em apoiá-la, porque está interessado em trazer coisas de fora, em trazer tecnologias, isso foi uma luta muito difícil! Você não pode imaginar, e com 
no lo había pensado. Que era como apoyar la investigación de la universidad en un sistema capitalista que no está interesado en apoyar eso, porque está interesado en traer cosas de afuera, en traer tecnologías, jeso fue una pelea durísima! No te imaginas, y con los de la Nacho ${ }^{7}$ y con todo el mundo peleé. Bueno, entonces desarrollo toda esta idea, que yo creo que se consolidó en todas las universidades del país, y se consolidó como esa especie de consultoría especializada y algo que sólo en la universidad puedes hacer.

Ahí se formó por ejemplo el laboratorio de hidráulica, el laboratorio de materiales y cosas de esas. Digamos que el cambio fue un cambio dramático, aunque nadie va a decir que fuí yo, pero sino no hubiera hecho eso, no habría todo eso. Pero cada persona que hizo lo que hizo, es la que se lleva los laureles de lo que hizo, como los laboratorios de hidráulica, los que lo hicieron son los que se llevan el crédito. Yo estaba detrás de todo eso, para armarlo, era una cosa administrativa mi papel, pero con filosofía, con un sentido de dirección, para dónde debe ir la Universidad y yo me agarré con el consejo directivo y con todo el mundo porque nadie quería eso, eso fue realmente un cambio importante en la Universidad, y no sólo en la Universidad de los Andes, se volvió un cambio en el país. Cuando yo consideré que ya había cumplido mi misión, me retire en el 89.

En esos seis años hice docencia, pero lo que más hice fue investigacion, hice muchos proyectos, proyectos buenísimos, muy interesantes, porque eran prácticos, yo creo que como la ingeniería es práctica, a mi no me interesa lo teórico. Por ejemplo, con el Estado hice un proyecto inmenso sobre la sistematización de las elecciones con la Registraduría del Estado Civil, que incluye elecciones y la identificación ciudadana, las cédula y todo eso. Ahí le dimos un vuelco a la Registraduría y las elecciones, fue la primera vez que el país supo en la noche quien había ganado las elecciones, porque usamos unos sistemas de información sofisticadÍsimos, con computadores, centros de computación, pero hay sitios en mula y en bicicleta, entonces inventamos correos en mula. Yo no sé, eso cambió después, ahora es muy eficiente, de lo más eficiente de América Latina.

Entonces cuando yo me retiré, dije: "mierda tengo

7 Forma coloquial de referirse a la Universidad Nacional de Colombia. o povo da $\mathrm{Nacho}^{7}$ e todos com quem briguei. Bem, então eu desenvolvi toda essa idéia, que eu acho que se consolidou em todas as universidades do país, e foi consolidada como esse tipo de consultoria especializada e algo que só na universidade você pode fazer.

Por exemplo, o laboratório de hidráulica, o laboratório de materiais e coisas assim foram formados. Digamos que a mudança foi dramática, embora ninguém vá dizer que fui eu, mas se eu não tivesse feito, não haveria tudo isso. Mas cada pessoa que fez o que fez, é quem fica com os louros pelo que fez, como os laboratórios hidráulicos, quem fez são os que ficam com os louros. Eu estava por detrás de tudo isso, para montar, meu papel era administrativo, mas com filosofia, com senso de direção, para onde a Universidade deveria ir e eu me agarrei ao conselho de diretores e a todos porque ninguém queria isso, isso foi realmente uma mudança importante na Universidade, e não apenas na Universidade dos Andes, tornou-se uma mudança no país. Quando eu considerei que já tinha cumprido a minha missão, aposentei-me em 89.

Nesses seis anos eu lecionei, mas o que mais fiz foi pesquisa, fiz muitos projetos, muito bons projetos, muito interessantes, porque eram práticos, acho que como a engenharia é prática, não estou interessado na teoria. Por exemplo, com o Estado fiz um grande projeto de sistematização de eleições com o Registro Civil, que inclui eleições e identificação do cidadão, as cédula e tudo isso. Foi uma reviravolta no Registro e nas eleições, foi a primeira vez que o país soube na mesma noite quem havia vencido as eleições, pois utilizamos sistemas de informação muito sofisticados, com computadores, centros de computação, mas há lugares em mulas e bicicletas, então inventamos os correios em mulas. Não sei, isso mudou mais tarde, agora é muito eficiente, um dos mais eficientes da América Latina.

Por isso, quando me aposentei, disse: "merda, tenho que fazer agora uma proposta da nova engenharia como tem que ser, mas não sei como fazê-lo". Então comecei a trabalhar com estudantes em micro, pequenas empresas, porque uma das coisas que tinha em mente era, e ainda tenho em mente, mas eles ainda não fizeram isso neste maldito país - é que as pessoas falam sobre isso, mas não o fazem. A base da riqueza, que é o povo, é desenvolver a capacidade

7 Forma coloquial de se referir à Universidade Nacional da Colômbia 
que hacer ahora si una propuesta de la nueva ingeniería como tiene que ser, pero yo no sé cómo hacerlo". Entonces empecé a trabajar con estudiantes en microempresas, pequeñas empresas, porque una de las cosas que yo tenía en mente era, y eso todavía lo tengo en mente, ipero todavía no lo han hecho en este puto país!, es que la gente habla de eso pero no lo hace. La base de la riqueza, que es la gente, es desarrollar la capacidad emprendedora de la gente y apoyar la capacidad emprendedora de la gente y por eso me metí en las MiPYMEs ${ }^{8}$ y todos mis estudiantes se fueron a trabajar en MiPYMEs, como parte de su proyecto de curso, hicimos 500 por lo menos, proyectos de pequeños sistemas de información en MiPYMEs y ahí salió el enfoque TESO $^{9}$ que era buscando que los trabajadores no fueran esclavos, sino autónomos y poder construir una empresa no dominadora, sino emancipatoria. Eso era muy arriesgado, me atacó hasta mi hermano, que me decía: "usted es mas boludo, que cosa mas absurda esa, en un país colonial venía a decir que la gente tiene que emanciparse, jestá loco!”. Si mi propio hermano me decía eso, imaginate lo me decía el resto de la gente, yo seguía silenciosamente trabajando y mis estudiantes eran felices y además las cosas tenían éxito y produjeron documentos de montones de empresas con ese enfoque, el enfoque era el de sistema de información que sin un desarrollo organizacional adecuado no tienen sentido y el desarrollo organizacional solo tiene sentido en cuanto las personas articulan su autonomía.

En realidad TESO fue un grupo de investigación que yo fundé con Gustavo González en el año 72, con la idea de mostrar cómo los grupos eran espacios para conversar alrededor de un tema determinado, el tema de TESO era la teoría de sistemas aplicada a las organizaciones, y cuando yo empecé a desarrollar el enfoque TESO, le puse así en homenaje al grupos.

\section{NGA: ¿Nos puedes contar más sobre el desarrollo del enfoque TESO?}

ELM: Eso era en el 88 cuando empecé el desarrollo, mi idea era que los estudiantes no estaban preparados para ser empresarios porque no estaban preparados para hacerse cargo de su vida y por eso tenían que ser empleados. Yo pensé que era muy importante desarrollar el espíritu emprendedor en la

8 Es un acrónimo de Micro, Pequeña y Mediana Empresa.

9 Teoría de Sistema en las Organizaciones. empreendedora do povo e apoiar a capacidade empreendedora do povo e é por isso que entrei nas $\mathrm{PMEs}^{8}$ e todos os meus alunos foram trabalhar em PMEs, como parte do seu projeto de curso, fizemos pelo menos 500 projetos de pequenos sistemas de informação em PMEs e surgiu a abordagem TESO ${ }^{9}$ que foi desenvolvida pensando nos trabalhadores não para serem escravos, mas para serem autônomos e para serem capazes de construir uma empresa que não fosse dominante, mas emancipatória. Isso foi muito arriscado, fui até atacado pelo meu irmão, que me disse: "você é estúpido, que coisa mais absurda de se dizer, num país colonial você veio dizer que as pessoas têm que ser emancipadas, você é louco! Se meu próprio irmão me disse isso, imagine o que o resto das pessoas me disseram. Eu continuei trabalhando silenciosamente e meus alunos estavam felizes. Também as coisas foram bem sucedidas e eles produziram documentos de muitas empresas com essa abordagem. A abordagem foi a do sistema de informação que sem um desenvolvimento organizacional adequado não faz sentido e o desenvolvimento organizacional só faz sentido assim que as pessoas articulam sua autonomia.

$\mathrm{Na}$ verdade, TESO foi um grupo de pesquisa que fundei com Gustavo Gonzalez em 72, com a idéia de mostrar como grupos eram espaços para falar sobre um determinado tema. O tema da TESO era teoria de sistemas aplicada às organizações, e quando comecei a desenvolver a abordagem TESO, nomeei-a em homenagem ao grupo.

\section{NGA: Você pode nos contar mais sobre o desenvol- vimento da abordagem TESO?}

ELM: Isso foi em 88 quando eu comecei o desenvolvimento, minha idéia era que os estudantes não estavam prontos para serem empreendedores porque não estavam prontos para assumir o controle de suas vidas e por isso eles tinham que ser empregados. Achei muito importante desenvolver o espírito empreendedor nas pessoas, mas um espírito empreendedor em que as relações humanas não fossem mediadas pelo poder, ou seja, pela intimidação uns pelos outros, mas sim pelo trabalho em conjunto, trabalhando em equipa e inspirado precisamente pela cibernética organizacional foi para mim desenvolver a TESO, mas à minha própria maneira. Porque a cibernética organizacional

8 É um acrônimo para Micro, Pequenas e Médias Empresas.

9 Teoria de Sistemas em Organizações. 
gente, pero un espíritu emprendedor en el cual las relaciones humanas no estuvieran mediadas por el poder, es decir: por el matoneo de unos por otros, sino por el trabajo conjunto, el trabajo en equipo e inspirado precisamente en la cibernética organizacional fue que yo desarrolle TESO pero a mi manera. Porque la cibernética organizacional plantea empresas muy jerárquicas y muy desde el control, y a mí me interesaba mucho desarrollar empresas donde lo importante no es la empresa sino el ser humano. Curiosamente yo empecé a descubrir ahí que tenía que ver mucho con el enfoque marxista pero desde otra perspectiva y esa idea del ser desalienado $\mathrm{O}$ sea el ser autónomo que se hace cargo de su vida, para quien el trabajo no es un castigo o una tortura sino la oportunidad de crecer como ser humano, porque cuando uno trabaja en lo que realmente le gusta y en lo que realmente tiene talento, uno desarrolla ese talento con gusto, siempre, y entonces digamos va estar siendo humano desde su práctica cotidiana.

\section{"Yo pensaba tenemos que} crear una sociedad que propicie el que las personas puedan desarrollarse desde sus talentos personales y esa sociedad debe partir de cosas chiquitas y yo empecé por empresas que eran empresas familiares.

\begin{abstract}
NGA: Esa relación de lo que tu llamas "vocación vital" o del gusto de la persona en qué momento de tu vida emerge, ¿siempre estuvo ahí desde pequeno esa importancia de vincular trabajo a algo que le guste a la gente?
\end{abstract}

ELM: Sí, porque yo me dí cuenta, que yo mismo estudié algo que no era lo que verdaderamente he debido estudiar y trabajé en lo que no me gustaba y no desarrollé mis talentos personales. Pero siempre fuí consciente de eso, yo pensaba tenemos que crear una sociedad que propicie el que las personas puedan desarrollarse desde sus talentos personales y esa sociedad debe partir de cosas chiquitas y yo empecé por empresas, que eran empresas familiares, posiciona as empresas de forma muito hierarquizadas e a partir do controle, e eu estava muito interessado em desenvolver empresas onde o importante não é a empresa, mas o ser humano. Curiosamente, comecei a descobrir que tinha muito a ver com a abordagem marxista, mas de outra perspectiva e essa ideia do ser alienado. Ou seja, o ser autônomo que toma conta da sua vida, para quem o trabalho não é um castigo ou uma tortura, mas a oportunidade de crescer como ser humano, porque quando se trabalha no que se gosta realmente e no que se tem realmente talento, desenvolve-se esse talento com prazer, sempre, e então, digamos que você será como um ser humano a partir de sua prática diária.

\section{»Eu pensava que temos que criar uma sociedade que permita às pessoas se desenvolverem a partir de seus talentos pessoais e que a sociedade deve começar a partir de coisas pequenas e eu comecei com empresas, que eram empresas familiares.}

\begin{abstract}
NGA: Essa relação do que você chama de "vocación vital" ou do gosto da pessoa em que momento de sua vida emerge? Sempre existiu desde a infância essa importância de ligar o trabalho a algo que as pessoas gostam?
\end{abstract}

ELM: Sim, porque eu percebi que eu estudei algo que não era realmente o que eu deveria ter estudado e trabalhei no que eu não gostava e não desenvolvi os meus talentos pessoais. Mas eu sempre tive consciência disso, pensei que temos que criar uma sociedade que permita às pessoas se desenvolverem a partir de seus talentos pessoais e que a sociedade deve começar a partir de coisas pequenas e eu comecei com empresas, que eram empresas familiares, geralmente as MPMEs são empresas familiares. Onde o objetivo era que as pessoas fossem autônomas e crescessem como pessoas, a partir da possibilidade de aprender e desenvolver sua própria vocação, seu próprio talento, sua própria paixão. Isso não é tão trivial porque nossa 
generalmente las MiPYMES son familiares. Donde se buscaba que la gente fuera autónoma y creciera como persona, desde la posibilidad 1de aprender y desarrollar su propia vocación, su propio talento, su propia pasión. Eso no es tan trivial porque nuestra sociedad es machista, conquistadora, es eso del macho blanco europeo, que puede clavarse a la india porque es de otro color y no es europea.

Esa es como la quintaesencia de lo que Césaire ${ }^{10}$ llama la colonialidad, hay otras quintaesencias, pero esa es muy importante. Césaire también habla de otras cosas que son importantes, yo en ese momento no conocía a Césaire, y es que la esencia de la colonialidad, es que el colonizador, que es macho blanco europeo despoja a las personas colonizadas de su capacidad creativa, las pone a trabajar para él y después les da limosna del producto que ellos le entregan, se lo devuelve en forma de limosna. Entonces le arranca la dignidad a las personas, porque la dignidad natural, emerge de la capacidad de dar aquello que uno ha creado, eso es muy bello, pero es muy cierto. Yo tenía esa intuición, pero no la tenía tan clara, y la desarrollé con mis estudiantes. Yo buscaba que estudiantes buscarán su vocación vital y se hicieran cargo de su vida y fueran por supuesto autónomos, cuando uno se hace cargo de su vida es autónomo. Eso no es tampoco trivial, como tú sabes es dificilísimo, por ejemplo las mujeres son sub-humanas en esta sociedad colonial, sólo son humanos los machos blancos europeos, son dominadas, clavadas. Un filósofo puertorriqueño, que se llama Nelson Maldonado Torres ${ }^{11}$ plantea eso que a mi me parece genial, es que no sólo las personas son subalternas, sino que son clavables, es decir, yo me puedo clavar al subalterno. Huy terrible porque toda teoría colonial plantea eso, es decir, la sociedad está concebida en términos de machos blancos que mangonean a los demás, a todos los demás no son blancos ni machos, así lo sean y se los puede clavar cuando sea, impunemente, y no pasa nada.

\footnotetext{
10 Aimé Césaire, fue un poeta y político martiniqués. Fue el ideólogo del concepto de la negritud y su obra ha estado marcada por la defensa de sus raíces africanas. Se considera uno de los precursores de los Estudios Poscoloniales.

11 El profesor Maldonado-Torres es profesor en el Departamento de Estudios Latinos y del Caribe y el Programa de Literatura Comparada en Rutgers School of Science and Arts de la State University of New Jersey.Sus temas de investigación son la Teoría comparativa crítica y decolonial, teorías de raza y etnia, feminismo decolonial, fenomenología y filosofía social y política. Recuperado el 6 de enero en: https://latcar.rutgers.edu/people/core-faculty/52-nelson-maldonado-torres
}

sociedade é machista, conquistadora, é a do homem branco europeu, que pode cravejar o índio porque é de outra cor e não é europeu. Isso é como a quintessência do que Césaire ${ }^{10}$ chama de colonialidade, existem outras quintessências, mas isso é muito importante. Césaire também fala de outras coisas que são importantes, eu não conhecia Césaire na época, a essência da colonialidade é que o colonizador, que é um homem branco europeu, esvazia o povo colonizado da sua capacidade criativa, coloca-o para trabalhar para ele e depois dá esmola ao produto que o povo lhe dá, ele devolve em forma de esmola. Então o colonizador tira a dignidade das pessoas, porque a dignidade natural emerge da capacidade de dar o que se criou, isso é muito bonito, é muito verdadeiro. Eu tinha essa intuição, mas não era tão clara para mim, e eu a desenvolvi com meus alunos. Eu procurava estudantes que procurassem sua vocação vital e se encarregassem de sua vida e fossem autônomos, é claro, quando alguém se encarrega de sua vida, é autônomo. Isso também não é trivial, como sabem é muito difícil, por exemplo, as mulheres são sub-humanas nesta sociedade colonial, apenas os homens brancos europeus são humanos, são dominadas, cravejados. Um filósofo porto-riquenho, cujo nome é Nelson Maldonado Torres ${ }^{11}$, diz algo que eu acho ótimo, que não só as pessoas são subalternas, mas são golpeáveis, ou seja, eu posso golpear o subalterno. Isso é terrível, porque toda teoria colonial propõe isto, ou seja, a sociedade é concebida em termos de homens brancos que dominam os outros, todos os outros não são brancos ou homens, e mesmo que sejam, podem ser golpeados quando quer que seja com impunidade e nada acontece.

\section{NGA: Você estava me dizendo como essa busca por "vocações vocacionais" surge quando você co- meça a desenvolver o TESO e sobre a importância de quebrar esses esquemas coloniais, isso surge intuitivamente?}

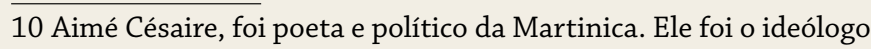
do conceito de negritude e seu trabalho foi marcado pela defesa de suas raízes africanas. É considerado um dos precursores dos estudos pós-coloniais

11 O professor Maldonado-Torres é professor do Departamento de Estudos Latinos e do Caribe e do Programa de Literatura Comparada da Escola de Ciências e Artes Rutgers da Universidade Estadual de Nova Jersey. Seus temas de pesquisa são teoria comparativa crítica e decolonial, teorias étnicas e raciais, feminismo descolonial, fenomenologia e filosofia social e política. Acessado em 6 de janeiro em: https://latcar.rutgers.edu/people/core-faculty/52-nelson-maldonado-torres 
NGA: Tu me estabas contando cómo emerge esa búsqueda de las "Vocaciones Vitales" cuando empiezas en el desarrollo de TESO y sobre la importancia de romper esos esquemas coloniales, ¿eso emerge de manera intuitiva?

ELM: Es que mi papá era eso, un macho blanco europeo insoportable, clavador universal, un asqueroso, pero era mi papá (risas), pero era terrible, él no tenía la culpa, ese era su rol en esta vida. Yo viví eso muy de cerca, del lado que no era o del lado que era, del lado que fue. Pero digamos que no lo sentía tan fuertemente como los empleados de él. Es posible que yo lo sintiera igual porque yo era el hijo y el hijo no es el macho blanco europeo, todos los demás son subalternos.

NGA: Entonces ¿TU empiezas a desarrollar TESO en los 80's con los estudiantes?

ELM: Yo ponía a trabajar a cada estudiante en una MiPYME, por eso es que salieron tantos trabajos, sobre diseño organizacional con enfoque TESO. Es decir, que las personas se desarrollan como seres humanos a través de su trabajo en la empresa y también diseñando la ingeniería necesaria para eso, que eran sistemas de información complementarios, yo les decía que era ingeniería de cola, no de punta (risas).

NGA: Ese cuerpo medianamente estable que llamas enfoque TESO ¿hasta qué momento los desarrollas?

ELM: Yo presenté un artículo, creo que en el 90, tal vez o antes, que se llama el Enfoque TESO, es es el primer artículo que yo publico sobre el enfoque TESO. Y a partir de ese artículo, que fue muy elogiado en la comunidad académica, algo que nunca antes me había pasado, ni me volvió a pasar. Yo creo que fue muy elogiado porque aun era muy técnico, cuando empiezo yo a meterme más con la "cosa social", ya empiezan a verme a mí como un poco demoníaco, como subversivo, porque no era macho blanco europeo, sino un cretino que trabajó con la gente.

NGA: ¿Cuándo dices que te empieza meter con "la cosa social" a que te refieres más específicamente?

ELM: Un ingeniero que trabaja en un empresa, trabaja para que la empresa produzca más y yo como ingeniero que trabajaba en la empresa, trabajaba
ELM: É que o meu pai era isso, um insuportável homem branco europeu, um agressor universal, um cretino, ele era o meu pai (risos), mas era terrível, ele não tinha culpa, esse era o seu papel nesta vida. Eu vivi isso muito de perto, do lado que ele não estava ou do lado que ele estava, do lado que fosse. Mas digamos que não senti isso de forma tão forte como os seus empregados. É possível que eu tenha sentido o mesmo porque eu era o filho e o filho não é o homem branco europeu, todos os demais são subalternos.

\section{NGA: Então você começou a desenvolver a TESO nos anos 80 com os alunos?}

ELM: Eu costumava colocar todos os alunos para trabalhar em uma MPME, por isso tantos trabalhos sobre design organizacional com a abordagem TESO foram realizados. Ou seja, as pessoas se desenvolviam como seres humanos através do seu trabalho na empresa e também projetando a engenharia necessária para isso, que eram os sistemas de informação complementares, eu dizia que era engenharia de rabo e não de ponta (risos).

\section{NGA: Aquele corpo moderadamente estável que} você chama de abordagem TESO, até que ponto você a desenvolve?

ELM: Eu apresentei um artigo, acho que em 90 talvez ou antes, que se chama a Abordagem TESO, é o primeiro artigo que eu publico sobre a abordagem TESO. Foi a partir desse artigo, que foi muito elogiado na comunidade acadêmica, algo que nunca me tinha acontecido antes, nem aconteceu de novo. Acho que foi muito elogiado porque ainda era muito técnico, quando começo a me envolver mais com a "coisa social", eles já começam a me ver como um pouco demoníaco, como subversivo, porque eu não era um homem branco europeu, mas um cretino que trabalhava com pessoas.

NGA: Quandovocê diz que começa a entrar nas "coisas sociais", o que você quer dizer especificamente?

ELM: Um engenheiro que trabalha em uma empre$\mathrm{sa}$, trabalha para que a empresa produza mais e eu, como engenheiro que trabalhava na empresa, trabalhei para que a empresa se tornasse um espaço de realização pessoal para aqueles que moravam lá, para aqueles que trabalhavam lá, e o importante não era a empresa, mas as pessoas. 
para que la empresa se convirtiera en un espacio de realización personal para los que la habitaban, los que trabajaban en ella, y lo importante no era la empresa sino las personas.

De ahí pa' delante lo trabajé siempre y eso fue derivando en "Comunidades de Aprendizaje". No me acuerdo cuando deriva, pero si me acuerdo que yo empecé a trabajar con comunidades de empresas y esas comunidades de empresas realmente eran comunidades de empresarios, y empecé a ver como esos empresarios colaboraban entre ellos. Y también empecé a ver que era insuficiente mirar la autonomía del individuo y mirar la cosas desde las perspectiva de lo individual, era mucho más interesante mirarlo desde la perspectiva de lo comunitario, es decir, del individuo en relación con alter, pero era una relación que no era de subalternidad, como dicen los teóricos, sino de alteridad, como dicen también los teóricos. Pero son dos tipos de teóricos, los primeros son los de la teoría decolonial y los otros son por ejemplo Levinas ${ }^{12}$, el filósofo, para mí ha sido inspirador, pero no solo Levinas, Buber $^{13}$ por ejemplo.

Ahí es donde emerge la importancia del diálogo, porque cuando tú estás trabajando en comunidad normalmente en toda la teoría organizacional que yo empecé a estudiar, que es la de los chilenos, de Fernando Flores ${ }^{14}$, Echeverria ${ }^{15}$, Maturana ${ }^{16}$ y otros... Miran el lenguaje como la posibilidad de coordinar acciones y a mí me interesaba el lenguaje como la capacidad de reconocer al otro, la capacidad de generar espacios de reconocimiento, y eso me llevó al diálogo, a la importancia del diálogo, por eso también Buber y Levinas son fundamentales. También hay que reconocer que en esos trabajos

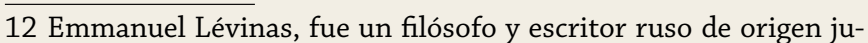
dío, consagró su vida y su obra a la reconstrucción del pensamiento ético después de la Segunda Guerra Mundial, que pasó confinado en un campo de concentración alemán y en la que casi toda su familia fue asesinada.

13 Martin Buber, filósofo y escritor judío austríaco-israelí.

14Carlos Fernando Flores, Ingeniero Civil Industrial, Doctor en Filosofía del Lenguaje, Político, Empresario y Emprendedor. Senador de la República de Chile, representa a la Región de Tarapacá por el período 2002- 2010. Miembro de la Comisión de Economía y de la Comisión Especial de Ciencia, Tecnología e Innovación.

15 Rafael Echeverría, es Sociólogo de la Universidad Católica de Chile y Doctor en Filosofía de la Universidad de Londres. Ha sido profesor en diversas universidades y consultor durante varios años de las Naciones Unidas.

16 Humberto Maturana es biólogo, filósofo y escritor chileno, Premio Nacional de Ciencias en 1994, junto a Francisco Varela, definió el concepto de autopoiesis.
De lá para a frente sempre trabalhei e isso derivou nas "Comunidades de Aprendizagem". Não me lembro quando surgiu, mas lembro que comecei a trabalhar com comunidades empresariais e essas comunidades empresariais eram realmente comunidades de empreendedores, e comecei a ver como esses empreendedores colaboravam uns com os outros. E também comecei a ver que era insuficiente olhar para a autonomia do indivíduo e olhar para as coisas a partir da perspectiva do indivíduo, era muito mais interessante olhar para ela a partir da perspectiva da comunidade, ou seja, do indivíduo em relação à alteridade, mas era uma relação que não era de subalternidade, como dizem os teóricos, mas de alteridade, como dizem também os teóricos. Mas há dois tipos de teóricos, os primeiros são os da teoria descolonial e os outros são, por exemplo, Levinas ${ }^{12}$, o filósofo, para mim ele tem sido inspirador, mas não apenas Levinas, Buber ${ }^{13}$, por exemplo.

É aí que surge a importância do diálogo, porque quando se trabalha em comunidade, normalmente e em toda a teoria organizacional que comecei a estudar, que é a dos chilenos, de Fernando Flores $^{14}$, Echeverria ${ }^{15}$, Maturana ${ }^{16}$ e outros, se considera a linguagem como a possibilidade de coordenar ações. Eu estava interessado na linguagem como a capacidade de reconhecer o outro, a capacidade de gerar espaços de reconhecimento, e isso me levou ao diálogo, à importância do diálogo, por isso Buber e Levinas também são fundamentais. Também devemos reconhecer que nesses trabalhos que eu fazia conheci um gringo, Barnett Pearce ${ }^{17}$, que

12 Emmanuel Lévinas, filósofo e escritor russo de origem judaica, dedicou a sua vida e obra à reconstrução do pensamento ético após a Segunda Guerra Mundial, quando passou confinado a um campo de concentração alemão e no qual quase toda a sua família foi morta.

13 Martin Buber, filósofo e escritor judeu austriaco-israelita.

14 Carlos Fernando Flores, Engenheiro Civil Industrial, Doutor em Filosofia da Linguagem, Político, Empreendedor e Empreendedor. Senador da República do Chile, representa a região de Tarapacá no período de 2002 a 2010. Membro da Comissão de Economia e Comissão Especial de Ciência, Tecnologia e Inovação.

15 Rafael Echeverría, é sociólogo da Universidade Católica do Chile e doutorado em Filosofia pela Universidade de Londres. Ele é professor em várias universidades e foi consultor por vários anos nas Nações Unidas.

16 Humberto Maturana é um biólogo, filósofo e escritor chileno, Prêmio Nacional de Ciência em 1994, juntamente com Francisco Varela, definiu o conceito de autopoiese.

17 Barnett Pearce, era tanto um acadêmico teórico e quanto um profissional praticante. Nos ambientes universitários, ele era mais conhecido por seu papel no desenvolvimento da teoria da Gestão Coordenada do Significado ou CMM. Escreveu sete livros e mais de cem artigos e capítulos. Foi visitante sênior do Linacre College, Uni- 
»En Comunidades de Aprendizaje si me parece que hay que hacer énfasis en el diálogo, y el diálogo es para comprender la situación. Ahí hay una cosa muy importante, el reconocimiento de sí mismo y el reconocimiento del otro, llevan a la capacidad, por lo menos latente, de reconocer el entorno, la situación en la que se está y el diálogo a mi juicio es el instrumento privilegiado para comprender, para comprenderse así mismo, como al otro, como a lo otro, a la situación en la que se está.
"Nas Comunidades de

Aprendizagem penso que a ênfase deve ser colocada no diálogo, e o diálogo serve para compreender a situação. Há aí algo muito importante, 0 reconhecimento de si mesmo e o reconhecimento do outro, que leva à capacidade, pelo menos latente, de reconhecer o ambiente, a situação em que se encontra; e o diálogo, em minha opinião, é o instrumento privilegiado para compreender a si mesmo, o outro e a situação em que se encontra. 
que yo estaba haciendo conocí un gringo, Barnett Pearce ${ }^{17}$, era una persona que estuvo en Colombia y trabajó conmigo. Él había trabajado en las comunidades gringas el diálogo, trabajaba en la construcción de proyectos comunitarios y descubrió la importancia del diálogo y me la comentó.

\section{NGA: ¿Qué cambio hay entre TESO y Comunidades de Aprendizaje?}

ELM: Hay un cambio importante de TESO a "Comunidades de Aprendizaje". En TESO trabajaba en empresas donde cada persona es un individuo autónomo, capaz de hacerse cargo de su vida, pero no me importaban tanto las relaciones, allá ellos que se resuelvan. Después, en Comunidades de Aprendizaje sí me parece que hay que hacer énfasis en el diálogo, y el diálogo es para comprender la situación. Ahí hay una cosa muy importante, el reconocimiento de sí mismo y el reconocimiento del otro, llevan a la capacidad, por lo menos latente, de reconocer el entorno, la situación en la que se está y el diálogo a mi juicio es el instrumento privilegiado para comprender, para comprenderse así mismo, como al otro, como a lo otro, a la situación en la que se está. Y el diálogo realmente tiene un poder impresionante, pues es lo que yo he experimentado.

Aquí hay que meter otro ingrediente, yo empiezo a trabajar ya en el 2000 en el área de Tecnología y Sociedad ${ }^{18} \mathrm{y}$ hay toda una carreta sobre los estudios de tecnología y sociedad y yo empiezo a preguntarme sobre ¿qué carajos es la tecnología? Y me doy cuenta, no sólo por mí, sino por la genealogía, precisamente, por mirar la historia de la tecnología, no sólo la historia, sino la relación de las persona con la tecnología y la filosofía de la tecnología. Entonces me empiezo a dar cuenta que el ser humano, es

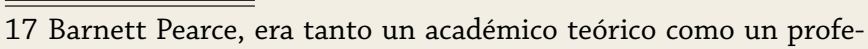
sional practicante. En entornos universitarios, fue mejor conocido por su papel en el desarrollo de la teoría de la Gestión Coordinada del Significado "o CMM. Escribió siete libros y más de cien artículos y capítulos. Fue miembro visitante senior en Linacre College, Universidad de Oxford, en 1989, y miembro Fulbright en Argentina en 1997. Antes de retirarse de Fielding Graduate University en 2008, fue miembro de la facultad de la Universidad de Dakota del Norte, Universidad de Kentucky, la Universidad de Massachusetts en Amherst y la Universidad Loyola de Chicago, en calidad de Presidente de los Departamentos de Comunicación de Massachusetts y Loyola. Tenía un doctorado de la Universidad de Ohio. https://www. taosinstitute.net/barnett-pearce

18 Los "Estudios Sociales sobre Ciencia y Tecnología", también conocidos como "Ciencia, Tecnología y Sociedad" (CTS), abarcan un campo transdisciplinar de estudios sobre los efectos culturales, éticos y políticos del conocimiento científico y la innovación tecnológica. estava na Colômbia e trabalhou comigo. Ele havia trabalhado o diálogo nas comunidades gringas, ele estava trabalhando na construção de projetos comunitários e descobriu a importância do diálogo e me falou sobre isso.

\section{NGA: Qual é a mudança entre a TESO e as Comuni- dades de Aprendizagem?}

ELM: Há uma mudança importante da TESO para "Comunidades de Aprendizagem". Na TESO trabalhei em empresas onde cada pessoa é um indivíduo autônomo, capaz de cuidar de sua própria vida, mas eu não me importava tanto com relacionamentos, lá eles que se resolviam entre si. Então, nas Comunidades de Aprendizagem penso que a ênfase deve ser colocada no diálogo, e o diálogo serve para compreender a situação. Há aí algo muito importante, o reconhecimento de si mesmo e o reconhecimento do outro, que leva à capacidade, pelo menos latente, de reconhecer o ambiente, a situação em que se encontra; e o diálogo, em minha opinião, é o instrumento privilegiado para compreender a si mesmo, o outro e a situação em que se encontra. O diálogo tem realmente um poder impressionante, foi o que eu experimentei.

Aqui tenho que colocar outro ingrediente, eu comecei a trabalhar em 2000 na área de Tecnologia e Sociedade $^{18}$ e hay toda um discurso sobre os estudos da tecnologia e da sociedade e começo a me perguntar: o que diabos é tecnologia? E percebo, não só por mim, mas pela genealogia, precisamente, olhando para a história da tecnologia, não só a história, mas a relação das pessoas com a tecnologia e a filosofia da tecnologia. Então eu começo a perceber que o ser humano é humano por causa da tecnologia. Os animais também podem ter tecnologia, mas é outra tecnologia. Mas a tecnologia humana é o que nos torna humanos, senão não estaríamos aqui, mas na selva sentados mastigando cajus ou coisas do gênero e não estaríamos fazendo

versidade de Oxford, em 1989, e membro da Fulbright na Argentina em 1997. Antes de deixar a Fielding Graduate University em 2008, foi membro da Universidade de Dakota do Norte, Universidade de Kentucky, Universidade de Massachusetts na Universidade em Amherst e da Universidade Loyola, em Chicago, como presidente dos departamentos de comunicação de Massachusetts e Loyola. Ele tinha um doutorado na Universidade de Ohio. Acesso em 7 de janeiro: https://www.taosinstitute.net/barnett-pearce

18 Os "Estudos Sociais sobre Ciência e Tecnologia", também conhecidos como "Ciência, Tecnologia e Sociedade" (CTS), cobrem um campo transdisciplinar de estudos sobre os efeitos culturais, éticos e políticos do conhecimento científico e da inovação tecnológica. 
»El lenguaje es una tecnología también, aunque es natural, es natural y no es natural, porque la gramática y todo eso no es nada natural. Es decir, nosotros cogemos lo natural

y lo transformamos y en el fondo está esa idea de que la tecnología es una prótesis, la tecnología nos permite tener prótesis que nos amplifican nuestra capacidad de acción y probablemente muchas otras cosas que yo no he pensado.

humano por la tecnología. Puede que los animales también tienen tecnologías, pero es otra tecnología. Pero la tecnología humana es la que nos hace humanos, sino fuera por eso no estaríamos aquí, sino en la selva sentados masticando marañones o cosas así y no estaríamos haciendo entrevistas ni nada, porque no nos interesaría.

NGA: ¿Antes de ese momento no había reflexión sobre la tecnología o eran reflexiones superficiales?, ¿Qué pasaba con el rol de la tecnología antes de que llegaras a los Estudios de Ciencia, Tecnología y Sociedad?

ELM: Sí, claro que yo reflexionaba sobre la tecnología porque estaba haciendo tecnología todo el tiempo, el diseño de sistemas de información es una tecnología. Lo que pasa es que después yo empiezo reflexionar más de fondo, más integralmente, inclusive que lo hacen los de CTS, sobre la relación corporal con la tecnología, que es lo que la hace humano. Usted no es humano sino tiene camisa, gafas y sombrero, sino que es un mico peludo, sentado frente ahí, masticando un plátano. Los asientos, ni las mesas existirían, así como los micos. Que si claro, cogen un palito y hurgan un panal, ese es nivel

\section{"A linguagem também é uma} tecnologia, embora seja natural, é natural e não é natural, porque a gramática e tudo isso não é nada natural. Em outras palavras, pegamos o que é natural e o transformamos, $e$ no cerne disso está essa idéia de que a tecnologia é uma prótese, a tecnologia nos permite ter próteses que ampliam nossa capacidade de ação e provavelmente muitas outras coisas que eu não tenha pensado.

entrevistas nem nada disso, porque não estaríamos interessados.

NGA: Antes desse tempo, não houve reflexão sobre a tecnologia ou foram reflexões superficiais? 0 que aconteceu com o papel da tecnologia antes de você se deparar com os Estudos de Ciência, Tecnologia e Sociedade?

ELM: Sim, é claro que eu estava refletindo sobre tecnologia porque eu estava fazendo tecnologia o tempo todo, o design de sistemas de informação é uma tecnologia. $\mathrm{O}$ que acontece é que mais tarde eu começo a refletir mais profundamente, de forma mais integral, inclusive os da CTS, sobre a relação corporal com a tecnologia, que é o que a torna humana. Você não é humano se não tem camisa, óculos e chapéu, mas é um macaco peludo, sentado na sua frente, mastigando uma banana. Os assentos, ou as mesas, não existiriam, assim como os macacos. É claro, você pega um pau e tenta fazer um paralelo, esse é o nível de tecnologia que você tem, porque o ser humano tem outro nível de tecnologia 
de tecnología que tienen, porque el ser humano tiene otro nivel de tecnología que es fundamental, el lenguaje. El lenguaje es una tecnología también, aunque es natural, es natural y no es natural, porque la gramática y todo eso no es nada natural. Es decir, nosotros cogemos lo natural y lo transformamos y en el fondo está esa idea de que la tecnología es una prótesis, la tecnología nos permite tener prótesis que nos amplifican nuestra capacidad de acción y probablemente muchas otras cosas que yo no he pensado.

\section{"Porque en últimas la cultura es artificial, es decir, todo lo que habitamos es artificio $y$ es tecnología.}

Digamos que las "Comunidades de Aprendizaje" se convierten en lo que Heidegger llama "hábitats" que son espacios construidos por el hombre con su tecnología, que son artificiales y en esos espacios artificiales constituimos nuestra identidad humana, es decir, nos hacemos personas, ahí, en esos espacios artificiales. Porque en últimas la cultura es artificial, es decir, todo lo que habitamos es artificio y es tecnología, y eso no lo habla casi ninguno de los que hablan de eso, y eso lo he armado yo, y puede que lo diga otro no lo sé, pero por lo menos lo he armado yo por mi cuenta, y no me importa si eso es original o no, jasí salió, su mercé!

Entonces, digamos que yo creo que la tecnología contemporánea, y ya llegó a la crítica de la tecnología, es dominadora porque proviene de todo el ethos dominador del europeo, está hecha para dominar la naturaleza y dominar los demás hombres.

NGA: Yo veo que el paso de TESO a "Comunidades de Aprendizaje" tiene dos vuelcos interesantes, uno es la aparición del diálogo como herramienta fundamental, con búsqueda de descentrar no solo la relación del individuo sino mirar el individuo con relación con otros y el otro, es una reflexión más profunda acerca de que es la tecnología, ¿hay otros elementos significativos en este cambio?

ELM: Si, hay una cosa también importante, en el diálogo es fundamental el diálogo consigo mismo y la capacidad de observación, es otro punto que a mi que é fundamental, a linguagem. A linguagem também é uma tecnologia, embora seja natural, é natural e não é natural, porque a gramática e tudo isso não é nada natural. Em outras palavras, pegamos o que é natural e o transformamos, e no cerne disso está essa idéia de que a tecnologia é uma prótese, a tecnologia nos permite ter próteses que ampliam nossa capacidade de ação e provavelmente muitas outras coisas que eu não tenha pensado.

\section{»Porque em última análise a cultura é artificial, ou seja, tudo o que habitamos é artificial é é tecnologia.}

Digamos que "Comunidades de Aprendizagem" se tornam o que Heidegger chama "habitats" que são espaços construídos pelo homem com sua tecnologia, que são artificiais e naqueles espaços artificiais nós constituímos nossa identidade humana, ou seja, nos tornamos pessoas, ali, naqueles espaços artificiais. Porque em última análise a cultura é artificial, ou seja, tudo o que habitamos é artificial e é tecnologia, e isso não é falado por quase ninguém que fala sobre isso, e eu tenho elaborado, e pode ser dito por outro que eu não conheço, mas pelo menos eu tenho elaborado sobre isso, e não me importo se é original ou não, saiu assim!

Portanto, digamos que eu acredito que a tecnologia contemporânea, e já chegou à crítica da tecnologia, é dominante porque vem de todo o ethos dominante do europeu, é feita para dominar a natureza e para dominar outros homens.

NGA: Vejo que a passagem da TESO para "Comunidades de Aprendizagem" tem duas reviravoltas interessantes, uma é a emergência do diálogo como ferramenta fundamental, procurando descentralizar não só a relação do indivíduo, mas olhar o indivíduo em relação aos outros; e a outra é uma reflexão mais profunda sobre o que é a tecnologia. Existem outros elementos significativos nesta mudança?

ELM: Sim, há uma coisa que também é importante. No diálogo é fundamental ter um diálogo consigo mesmo e a capacidade de observação é outro ponto 
me pareció genial cuando aparecieron las "Comunidades de Aprendizaje". Hay tres tipos de relaciones que yo busco que observemos las relaciones de poder, de comunicación y de producción. En las de poder yo observo si hay intentos dominadores o no, si hay intentos dominadores no puede haber diálogo. Para que haya diálogo tiene que haber igualdad de oportunidades, por decirlo así. Cuando tú me estás mangoneando y yo veo que estás ejerciendo poder sobre mí, yo con éstas herramientas digo aja, el me esta tratando de dominar. Entonces yo puedo optar (a) por dejarme dominar, pero ya sabiendo, ya me "doy cuenta", y eso es muy importante, porque es distinto cuando uno se deja dominar y no se da cuenta, cuando lo ve como antinatural, ya es consciente y se deja mangonear si no hay más remedio, pero con conciencia, eso es un paso crucial; (b) pero también puedo decir "usted me está mangoneando" usted tiene poder sobre, entonces podemos negociar qué hacer con eso.

"Yo creo que la tecnología contemporánea, y ya llegó a la crítica de la tecnología, es dominadora porque proviene de todo el ethos dominador del europeo, está hecha para dominar la naturaleza y dominar los demás hombres.

\begin{abstract}
NGA: Tu hablas de desnaturalizar estas relaciones de poder ¿en ese momento emerge esa idea del "darse cuenta" o eso viene de antes?
\end{abstract}

ELM: Es contemporánea, el "darse cuenta" es fundamental porque cuando yo observo que tú tienes una relación de poder "sobre", yo me "doy cuenta", pero el darme cuenta no es suficiente. Pero cuando me "dí cuenta", de que me "dí cuenta", es cuando yo aprendo de eso. Yo dijo "aja" yo tengo ese poder de "darme cuenta", y si estoy mangoneado y por ejemplo tu eres un capataz en una granja azucarera, yo no te puedo decir "usted me está mangoneando" porque eso es obvio, pero si me puedo dar cuenta de que tú me magoneas, y "darme cuenta" de que me "dí cuenta" y veo a ver que hago con eso. Eso ya yo lo dejo en manos de la persona que se hace cargo que me parece genial quando aparecem as "Comunidades de Aprendizagem". Há três tipos de relações que eu quero que olhemos: relações de poder, relações de comunicação e relações de produção. Nas de poder observo se há tentativas de dominação ou não, se há tentativas de dominação não pode haver diálogo. Para que haja diálogo tem de haver igualdade de oportunidades, por assim dizer. Quando você está me manipulando e eu vejo que você está exercendo poder sobre mim, com essas ferramentas eu digo: ele está tentando me dominar. Então eu posso escolher (a) me deixar dominar, mas já sabendo, já "percebi", e isso é muito importante, porque é diferente quando você se deixa dominar e não percebe, quando você vê isso como não natural, você já está ciente e se deixa dominar se não há outra escolha, mas com consciência, esse é um passo crucial; (b) mas também posso dizer que "você está me manipulando" você tem poder sobre isso, então podemos negociar o que fazer com a situação.

\section{"Eu acredito que a tecnologia} contemporânea, e já chegou à crítica da tecnologia, é dominante porque vem de todo o ethos dominante do europeu, é feita para dominar a natureza e para dominar outros homens.
NGA: Você fala em desnaturalizar essas relações de poder. É aí que surge a idéia de "conscientização", ou vem de antes?

ELM: É contemporânea, "dar-se conta" é fundamental porque quando eu observo que você tem uma relação de poder "sobre", eu "percebo", mas a realização não é suficiente. Mas quando eu me "dou conta" que eu "me dei conta", é quando eu aprendo com isso. Eu disse "aha", eu tenho esse poder de "dar-me conta", e se eu estou sendo manipulado e, por exemplo, você é um capataz numa fazenda de açúcar, eu não posso dizer "você está me manipulando" porque isso é óbvio, mas eu posso "me dar conta" que você está me manipulando, e me "dar conta" que eu "me dei conta" e ver o que eu faço com isso. Deixo isso para a pessoa que toma conta 
» En el diálogo es fundamental el diálogo consigo mismo y la capacidad de observación, es otro punto que a mi me pareció genial cuando aparecieron las "Comunidades de Aprendizaje". Hay tres tipos de relaciones que yo busco que observemos las relaciones de poder, de comunicación y de producción.
"No diálogo é fundamental ter um diálogo consigo mesmo e a capacidade de observação é outro ponto que me parece genial quando aparecem as "Comunidades de Aprendizagem". Há três tipos de relações que eu quero que olhemos: relações de poder, relações de comunicação e relações de produção.

da própria vida, ao contrário de los mamertos que dizem "há relações de poder" e também especificam o que precisa ser feito, por exemplo, uma revolução violenta. Não, para mim todos vão ver o que podem fazer, não tenho de dizer às pessoas o que fazer.

NGA: Eu sinto que talvez haja uma orientação criativa depois dessa "conscientização", você permite uma liberdade na qual a pessoa toma a decisão que quer com a própria vida, mas se há um incentivo para que essa decisão se torne um elemento criativo, um empreendimento, um ofício, algo que constrói. Estamos entendendo certo?

ELM: Sim, sim, mas isso tem a ver com construirse a si mesmo. Como há três tipos de relações que eu sugiro que você olhe: as de poder, as de comunicação e as de produção. Como é a minha comunicação com você? Se é eficaz, se não é eficaz, se é dialógica, se não é dialógica, obviamente se há relações de "poder sobre", não há diálogo. Logo me dou conta das relações de comunicação e da influência que isso tem nas relações de produção. Que são como me relaciono com o que produzi, com o meu produto e, então, se há relações de "poder sobre" mim, que me dizem o que tenho que fazer, minha relação com o produto é alienada, mas eu "me dou conta" e a coisa mais importante é "dar-se conta". Porque isso te move, quando você se conscientiza, isso lhe atira em algum lugar, ou você se mata ou engana o chefe ou você conversa com o chefe, ou você muda de emprego ou sei lá. Isso não é fácil, é claro! Se 
fácil claro!, si yo soy un obrero azucarero, ¿que voy a conseguir? otro puesto en otro ingenio, ¡Pero yo veré! De pronto no, yo pongo un puesto de tamales ${ }^{19}$ de Cartago en una esquina de Palmira, alguna cosa, pero digamos que el "darse cuenta" es verdaderamente el motor de la acción, el "darse cuenta" de las rupturas en las cuales yo estoy metido, y ahí metí otra palabra que son los "quiebres" o "rupturas", eso es Heideggeriano.

Las personas entonces hacen lo que les gusta hacer o lo que pueden, pero lo importante es que se "den cuenta", porque si hace lo que puede, por ejemplo y se "da cuenta" que puede más, entonces está buscando cambiar. Porque se "dio cuenta" que podía más, es posible que no lo logre y ahí tiene su libre albedrío, puede deprimirse o suicidarse, pero también puede decir un momentico ja la porra con todo eso, yo voy a hacer otra cosa! Pero yo en eso no digo que es lo que tiene que hacer, que cada uno decida.

NGA: ¿Qué papel tienen esas "rupturas" o "quiebres" en la transformación del sujeto y de la comunidad?

ELM: Pues eso si en cada caso es distinto, depende de los sujetos y yo no quiero teorizar sobre eso. Precisamente me pareció lo más interesante es dejar a ver que pasa. Si todos se dan cuenta pasan cosas, y pasan cosas asombrosas, además porque yo ya lo he vivido. Ese "darse cuenta" verdaderamente transforma la comunidad y transforma a las personas.

NGA: Después de madurar este enfoque Comunidades de Aprendizaje ¿Qué pasa?

ELM: Yo empiezo trabajar por ejemplo con las comunidades en guerra, pero ahi la política es pérfida y nos tranca. Porque era en la época de Álvaro Uribe y él mandó a decir que nosotros estábamos haciendo lo que no toca. Lo que pasa es que las comunidades en guerra fueron una oportunidad dentro del gobierno de Uribe, que fue bien interesante. Ellos creyeron que era una forma de apaciguar a las comunidades y cuando vieron que era al revés, pues nos cortaron la cabeza. Pero ahí alcanzamos a trabajar con doscientas y pico comunidades. Yo comienzo trabajar a finales del 2000 con las comunidades marginales en Bogotá y eso

19 El tamal es un alimento de origen mesoamericano preparado generalmente a base de masa de maíz, arroz rellena de carnes, vegetales y otros ingredientes. eu sou açucareiro, o que vou conseguir? Outro posto em outro engenho? De repente não, coloco um posto de venda de tamales ${ }^{19}$ de Cartago num canto de Palmira, alguma coisa, mas digamos que "se dar conta" é verdadeiramente o motor da ação, "darse conta" das rupturas em que estou envolvido, e lá coloquei outra palavra que é "rupturas", que é Heideggeriano.

As pessoas então fazem o que gostam de fazer ou o que podem, mas o importante é que se "dêem conta", porque se fazem o que podem, por exemplo, e "se dão conta" que podem fazer mais, então estão à procura de mudança. Porque ele se conscientizou que podia fazer mais, é possível que não consiga e tem o seu livre arbítrio, pode ficar deprimido ou cometer suicídio, mas também pode dizer por um momento: que se dane tudo isso, vou fazer outra coisa! Mas não estou dizendo que é isto que têm de fazer, que cada um decida o que fazer.

\section{NGA: Que papel desempenham estas "rupturas" na transformação do sujeito e da comunidade?}

ELM: Bem, isso é diferente em cada caso, depende dos sujeitos e eu não quero teorizar sobre isso. Precisamente, acho que o mais interessante é ver o que acontece. Se todos se conscientizam, coisas acontecem, e coisas incríveis acontecem, também porque eu já vivenciei isso. Esta "conscientização" transforma realmente a comunidade e transforma as pessoas.

\section{NGA: Depois de amadurecer a abordagem das Co- munidades de Aprendizagem, o que acontece?}

ELM: Eu começo a trabalhar, por exemplo, com comunidades em guerra, mas lá a política é perversa e nos prende. Porque foi na época de Álvaro Uribe, e ele mandou dizer que estávamos fazendo algo que não cabia a nós fazermos. O que acontece é que as comunidades em guerra foram uma oportunidade dentro do governo de Uribe que foi muito interessante. Eles pensaram que era uma forma de pacificar as comunidades e quando viram que era ao contrário, cortaram-nos a cabeça. Mas lá conseguimos trabalhar com duzentas e poucas comunidades. Comecei a trabalhar no final de 2000 com as comunidades marginais em Bogotá e isso é tremendamente interessante. Também com

19 Tamale é um alimento de origem mesoamericana preparado geralmente à base de massa de milho, arroz recheado com carnes, legumes e outros ingredientes. 
es tremendamente interesante. También con entidades públicas como Colciencias y el Acueducto. En Colciencias desarrollamos una "Comunidad de Aprendizaje" sobre lo que es el Sistema Nacional de Ciencia y Tecnología, que es un sistema de aprendizaje según nuestra concepción, no desde la concepción de ellos. Ahí trabajamos y fue muy interesante, claro les pareció atroz y nos echaron y no funciono, pero bueno. En el acueducto trabajamos con los obreros también construyendo " $\mathrm{Co}$ munidad de Aprendizaje", ahí no nos echaron, ellos quedaron muy contentos con este trabajo porque los obreros se volvieron más creativos, productivos y capaces de autogestionar su propio aprendizaje y esa fue una experiencia bien chusca que trabajamos en varias ocasiones, empezamos en 2014 y trabajamos la última vez en el 2018.

NGA: Cuando te abres a trabajar en otras comunidades diferentes a las empresas ¿qué aprendizajes vinieron a ti?

ELM: Pues para mí es importante la idea, de que construir comunidad es posible siempre, en una empresa, en un hogar, en fin. Empieza uno a ver que esto tiene un cantidad de oportunidades, precisamente porque la gente se empodera, la gente desarrolla una idea de que "hola, si se puede, claro que puedo y puedo con los otros", no sólo. Ese es un punto que a mí me parece crucial, es el trabajo comunitario, es poder trabajar en equipo. $Y$ es entender lo importante que es el diálogo para poder comprender las relaciones interpersonales en que andamos.

\section{NGA: Además de todos estos hitos históricos que me has contado ¿hay algún otro que te haya marca- do para hacer estas prácticas que nos has contado?}

ELM: Yo creo que una cosa que me movíó mucho, fue darme cuenta de la incapacidad de hacerse cargo de su vida que tiene el hombre colombiano. El hombre colombiano, claro, es el hombre y la mujer obviamente, pero yo no uso ese lenguaje inclusivo, me parece culisimo. A mi me impactaba mucho en esta hacienda feudal en la que crecí, ese mangoneo que hacía mi papá sobre los demás, qué hacía mi mamá sobre el servicio doméstico, que hacía el servicio doméstico sobre nosotros, los niños. Todos estaban tratando de mangonear a los demás, y a mí eso, no sé, siempre me ha parecido inadmisible.

Creo que yo te he contado esa historia, cuando mi entidades públicas como Colciencias e o Aqueduto. Em Colciencias desenvolvemos uma "Comunidade de Aprendizagem" sobre o que é o Sistema Nacional de Ciência e Tecnologia, que é um sistema de aprendizagem de acordo com a nossa concepção, não a partir da concepção deles. Trabalhamos lá e foi muito interessante, claro que eles acharam atroz e nos expulsaram e não funcionou, mas bom... No aqueduto trabalhamos com os trabalhadores também construindo "Comunidade de Aprendizagem", lá eles não nos expulsaram, eles ficaram muito felizes com este trabalho porque os trabalhadores se tornaram mais criativos, produtivos e capazes de autogerir sua própria aprendizagem e essa foi uma experiência muito boa que trabalhamos em várias ocasiões, começamos em 2014 e trabalhamos pela última vez em 2018.

\section{NGA: Quando você se abre para trabalhar em ou- tras comunidades diferentes das empresas, quais aprendizagens vêm até você?}

ELM: Bem, para mim é importante a ideia de que construir comunidade é sempre possível, em uma empresa, em uma casa, enfim... Você começa a ver que isso tem muitas oportunidades, justamente porque as pessoas se empoderam, as pessoas desenvolvem uma idéia de que "sim, é possível, é claro que eu posso e eu posso com os outros", não só. Esse é um ponto que me parece crucial, é o trabalho comunitário, é poder trabalhar em equipe. E é compreender como é importante o diálogo para poder compreender as relações interpessoais em que nos encontramos.

\section{NGA: Além de todos esses marcos históricos que você me contou, há algum outro que o marcou no exercício dessas práticas que você nos contou?}

ELM: Eu acho que uma coisa que me comoveu muito foi perceber a incapacidade do homem colombiano de tomar conta da sua vida, o homem colombiano, é claro, é o homem e a mulher, obviamente, mas eu não uso essa linguagem inclusiva, me parece idiota. Fiquei muito impressionado com esta propriedade feudal onde cresci, com a manipulação do meu pai sobre os outros, com o que a minha mãe fez sobre o serviço doméstico, com o que o serviço doméstico fez sobre nós, crianças. Todos estavam tentando dominar as pessoas, e eu não sei, isso sempre me pareceu uma coisa inaceitável de se fazer.

Acho que já contei essa história, quando o meu pai 
papá parado en el portón inmenso de nuestra casa, que estaba rodeado de unos jardines divinos. Se había entrado una vaca de un campesino. La vaca de Don Raimundo se entró al jardín y por decir algo se comió los agapantos y mi papa tenia un sistema que era: vaca que se mete al jardín la decomisamos y entonces le decomisaron la vaca al señor. El señor con su sombrerito decía: "Ay Don Alfonso la vaquita que da la leche de mis nietecitos", mi papá. "Se comió los agapantos", "Ay Don Alfonso pero nos vamos a quedar sin leche mañana para el desayuno", "Se comió los agapantos", "Pero Don Alfonso", "Raimundo la ley es la ley, adiós" y yo detrás viendo eso y pensando Don Raimundo es un tipo muy respetable como lo maltratan de esa manera ¡Que vaina tan horrible! Y yo era un niño muy sensible a mi eso me afectó terriblemente y yo no me puse del lado de mi papa, sino del lado de Don Raimundo.

\section{NGA: Nos has contado de muchas experimenta- ciones de trabajo en la frontera "Nepantla" y del aprender haciendo ¿has logrado experimentar con otros lenguajes artísticos?}

ELM: El libro que estoy escribiendo como tu sabes, le estoy haciendo dibujos en rapidógrafo. Yo tambien escribo mucho y hablo, tu vez como hablo, así como hablo, hablo y hago poesía. Ese dibujo del viejito con rulos es poesía:

El ojo que ves

No es ojo porque tú lo veas

Es ojo por te ve $\mathrm{e}^{20}$

Y si el ojo que te ve

Es tu ojo

Te inflamaras en tu ilusión

Pues el dibujo también lo utilizamos mucho en nuestro trabajo, en los "cuadros enriquecidos"21, ponemos a la gente a dibujar como sea. Y hemos trabajado con la gente que escriba poemas que como se siente y con dibujos. Con música tu lo viste, es genial, la música conecta mucho. Toda la vida he trabajado con dibujo y poesía. Creo que es muy importante la auto-expresión en cada uno.

20 Las tres primeras líneas son de Machado y Ernesto lo complementa con un comentario.

21 Los cuadros pictóricos (llamados también gráficos enriquecidos) fueron desarrollados particularmente como parte de la Metodología de los Sistemas Sistemas Suaves por Checkland, para recopilar información sobre una situación problema y como un medio para comunicarse fácilmente con los interesados utilizando símbolos en lugar de palabras. Checkland, Peter. Systems Thinking Systems Practice. John Wiley and Sons, 1981. estava no portão enorme da nossa casa, que estava rodeado por alguns jardins divinos. Tinha entrado uma vaca de um camponês. A vaca de Dom Raimundo entrou no jardim e comeu os agapantos; e meu pai tinha um sistema que era: vaca que entra no jardim nós a confiscamos e, então, eles confiscaram a vaca do senhor. O senhor de chapéu disse: "Ali está Dom Alfonso, a vaquinha que dá o leite aos meus netos", meu pai: "Ela comeu o agapanto", "Ah, Don Alfonso, mas amanhã vamos ficar sem leite para o café da manhã", "Ela comeu o agapanto", "Mas Don Alfonso", "Raimundo a lei é a lei, adeus" e eu estava atrás vendo isso e pensando que Don Raimundo é um cara muito respeitável, como maltratam-no dessa maneira? Que coisa horrível. E eu era uma criança muito sensível e isso me afetou terrivelmente e não fiquei do lado do meu pai, mas do lado de Don Raimundo.

\section{NGA: Você nos contou muitas experiências de tra- balho na fronteira "Nepantla" e sobre aprender fazendo.Você conseguiu experimentar outras lin- guagens artísticas?}

ELM: Para livro que estou escrevendo, como você sabe, estou fazendo desenhos em um velocímetro. Eu também escrevo muito e falo, você vê como eu falo. Assim como falo, eu falo e faço poesia. Aquele desenho do velho com rolinhos é poesia:

El ojo que ves

No es ojo porque tú lo veas

Es ojo por te ve $\mathrm{e}^{20}$

Y si el ojo que te ve

Es tu ojo

Te inflamaras en tu ilusión

E usamos muito desenho também em nosso trabalho, nas "figuras ricas" 21 , colocamos as pessoas para desenhar de qualquer maneira. E trabalhamos com pessoas que escrevem poemas sobre como se sentem e com desenhos. Com música você viu, é ótimo, a música conecta muito. Toda a minha vida trabalhei com desenho e poesia. Eu acho que a auto-expressão é muito importante para cada um.

20 As três primeiras linhas são de Machado e Ernesto complementa com um comentário.

21 As figuras ricas foram desenvolvidas especialmente como parte da Metodologia de Sistemas Soft Systems da Checkland, para reunir informações sobre uma situação problemática e como um meio de se comunicar facilmente com as partes interessadas usando símbolos em vez de palavras. Checkland, Peter. Prática de sistemas de pensamento sistêmico. John Wiley e Sons, 1981. 


\section{NGA: En todo este recorrido ¿tu has visto cambios significativos en cómo se ejerce la ingeniería en Colombia?, ¿qué futuro le ves?}

ELM: Sí, claro que ha cambiado y no le veo futuro. Yo lo que veo es una corrupción rampante que ha permeado la ingeniería y ha hecho que una ingenieria bastante buena, que era la ingeniería civil, por lo menos en Colombia, pero también la ingeniería eléctrica, que tenía muchos defectos también, pero era buena, tenía calidad. Está perrateado, todo está permeado por la corrupción, ique horror!, ¿como puede ser que nosotros seguimos sin ser capaces de terminar carreteras?, seguimos sin ser capaces de hacer puentes que no se caigan. Ese puente de un pueblo en Santander ${ }^{22}$ que se rizó todo, ¡no, no, no!, !eso es una vergüenza! Y las carreteras llenas de huecos, es inadmisible la falta de calidad en la ingeniería.

NGA: ¿Pero tu sientes que si ha habido un aumento en la corrupción?, ¿antes había una mejores prácticas?

ELM: Si, claro, yo vi hacer la autopista norte, esa la hicieron con todas las especificaciones, tenia defectos claro. Acá siempre hemos sido un poco perratas, acá no se hacen las cosas a lo bien y a lo grande, sino todo como en chiquito. Eso por ejemplo es un problema serio de la ingeniería nuestra, que no tenemos la capacidad de pensar en grande.

El futuro, que no veo, es que yo creo que hay que cambiar radicalmente una tecnología dominadora a una tecnología emancipatoria. Y eso implica un cambio de fondo en la tecnología, pero no te sé decir cómo es, porque eso está por venir. Pero la tecnología no puede ser, alinear a la gente con redes sociales y todas esas cosas en las que la gente se convierte como en un zombi y ya zombi los pueden manipular los cuatro dueños del poder mundial, ¡Eso es inadmisible! Pero lo admitimos todos. Dicen que no entienden esas revueltas, la gente se revuelve por esa cosas también, sin saber, sin saber qué es lo que los atenaza. Pero la gente sabe muy bien que está jodida y que está insatisfecha con los sistemas de gobierno. Y eso de las redes sociales es el sistema de gobierno y de domniacion mas sotificado que puede haber.

22 El Heraldo. Invías revela anomalías en el puente Hisgaura, en Santander. Recuperado el 6 de enero en: https://www.elheraldo.co/ colombia/invias-revela-anomalias-en-el-puente-hisgaura-en-santander-562788
NGA: Ao longo desta jornada, você viu mudanças significativas em como a engenharia é exercida na Colômbia? Que futuro você vê?

ELM: Sim, claro que mudou e não vejo futuro. O que vejo é uma corrupção desenfreada que permeou a engenharia e fez uma engenharia muito boa, que era engenharia civil, pelo menos na Colômbia, mas também engenharia elétrica, que tinha muitos defeitos, mas era boa, tinha qualidade É perrateado, tudo é permeado pela corrupção, que horror! Como é que podemos continuar sem conseguir terminar estradas? Ainda não conseguimos fazer pontes que não caem. Aquela ponte de um povoado em Santander ${ }^{22}$ que enrolou tudo, não, não, não! Isso é uma vergonha! $\mathrm{E}$ as estradas cheias de buracos, a falta de qualidade na engenharia é inaceitável.

\section{NGA: Mas você acha que houve um aumento na co- rrupção? Antes havia práticas melhoresr?}

ELM: Sim, claro, eu vi construírem a estrada norte, que foi feita com todas as especificações, ela tinha defeitos, é claro. Aqui sempre fomos um pouco chatos, aqui as coisas não são bem feitas e em grande estilo, mas tudo pequeno. Isso, por exemplo, é um problema sério da engenharia, que não temos capacidade de pensar grande.

O futuro, que não vejo, é que acredito que uma tecnologia dominante deve ser radicalmente alterada para uma tecnologia emancipatória. E isso implica uma mudança fundamental na tecnologia, mas não sei como lhe dizer como é, porque isso ainda está por vir. Mas a tecnologia não pode ser alinhar as pessoas com as redes sociais e todas aquelas coisas nas quais as pessoas se tornam zumbis e já podem ser manipuladas pelos quatro donos do poder mundial, isso é inadmissível! Todos nós admitimos isso. Eles dizem que não entendem essas revoltas, as pessoas também se mexem com essas coisas, sem saber, sem saber que é o que as prende. Mas as pessoas sabem muito bem que estão ferradas e insatisfeitas com os sistemas governamentais. $\mathrm{E}$ isso das redes sociais é o sistema de governo e dominação mais solidificado do que pode haver.

NGA: Vendo sua biblioteca e através da entrevista, senti que a filosofia é muito importante no

22 El Heraldo. Invias revela anomalias na ponte Hisgaura em Santander. Acessado em 6 de janeiro de 2020 em: https://www.elheraldo.co/colombia/invias-revela-anomalias-en-el-puente-hisgaura-ensantander-562788 
NGA: Viendo tu biblioteca y a través de la entrevista he sentido que es muy importante la filosofía en tu forma de vivir, ya has nombrado algunos filósofos europeos y otros latinoamericanos, solo me queda por preguntar ¿qué otros pensadores nos puedes recomendar?

ELM: No he mencionado otros latinoamericanos que para mi son muy importantes y no he descubierto hace mucho tiempo, como por ejemplo Maldonado Torres, Enrique Dussel. Todos los de la decolonialidad que son filósofos realmente, pero algunos me gustan más que otros, por ejemplo Walter Mignolo me gusto mucho, Anibal Quijano ${ }^{23}$. Para mi hay un pensador que adoro, siglo III AC, que es Chuang Tse ${ }^{24}$, él es Taoísta, un discípulo de Lao-Tse.

23 Aníbal Quijano Obregón fue un sociólogo y teórico político peruano. Fue profesor en la Universidad Nacional Mayor de San Marcos hasta 1995. Desde 1986 fue profesor de la Universidad de Binghamton, en Binghamton, Nueva York, Estados Unidos.

24 Zhuangzi, Chuang Tzu o Chuang Tse fue un filósofo de la antigua China que vivió alrededor del siglo IV a. C. durante el período de los Reinos combatientes, y que corresponde a la cumbre del pensamiento filosófico chino de las Cien escuelas del pensamiento. seu modo de vida, você já nomeou alguns filósofos europeus e outros latino-americanos, tenho que perguntar que outros pensadores você pode recomendar?

ELM: Não mencionei outros latino-americanos que são muito importantes para mim e não os descobri há muito tempo, como Maldonado Torres, Enrique Dussel. Toda os da decolonialidade que são realmente filósofos, mas alguns que eu gosto mais do que outros, por exemplo Walter Mignolo, gostei muito, Anibal Quijano ${ }^{23}$. Para mim, há um pensador que eu adoro, no século III aC, que é Chuang $\mathrm{Tse}^{24}$, ele é taoísta, um discípulo de Lao-Tse.

23 Aníbal Quijano Obregón era um sociólogo e teórico político peruano. Ele foi professor na Universidade Nacional de San Marcos até 1995. Desde 1986, foi professor na Universidade de Binghamton, em Binghamton, Nova York, Estados Unidos.

24 Zhuangzi, Chuang Tzu ou Chuang Tse era um antigo filósofo chinês que viveu por volta do século IV AC durante o período dos Reinos Combatentes e corresponde à cúpula do pensamento filosófico chinês das cem escolas de pensamento.
Así nos despedimos, nos dimos con un fuerte abrazo agradeciéndonos por la conversación fluida y por sacar a flote historias que antes no se habían contado. Continuamos tomando el sol, divagando sobre nuestra cotidianidad y con la promesa de sembrar un árbol de borrachero en 2020.
Assim nos despedimos, demos um grande abraço, agradecendo pela conversa fluida e pelas histórias flutuantes que não haviam sido contadas antes. Continuamos tomando banho de sol, divagando sobre nossas vidas diárias e com a promessa de plantar uma árvore de trombetas (borrachero) em 2020. 